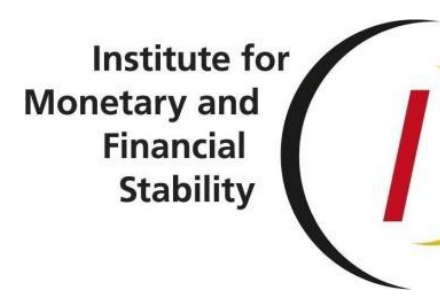

\author{
FLORIAN DEUFLHARD \\ DIMITRIS GEORGARAKOS \\ ROMAN INDERST
}

Financial Literacy and Savings Account Returns

Institute for Monetary and Financial Stability

GOETHE UNIVERSITY FRANKFURT AM MAIN

WORKING PAPER SERIES No. 88 (2015) 
This Working Paper is issued under the auspices of the Institute for Monetary and Financial Stability (IMFS). Any opinions expressed here are those of the author(s) and not those of the IMFS. Research disseminated by the IMFS may include views on policy, but the IMFS itself takes no institutional policy positions.

The Institute for Monetary and Financial Stability aims at raising public awareness of the importance of monetary and financial stability. Its main objective is the implementation of the "Project Monetary and Financial Stability" that is supported by the Foundation of Monetary and Financial Stability. The foundation was established on January 1, 2002 by federal law. Its endowment funds come from the sale of $1 \mathrm{DM}$ gold coins in 2001 that were issued at the occasion of the euro cash introduction in memory of the D-Mark.

The IMFS Working Papers often represent preliminary or incomplete work, circulated to encourage discussion and comment. Citation and use of such a paper should take account of its provisional character.

\section{Institute for Monetary and Financial Stability}

Goethe University Frankfurt

House of Finance

Theodor-W.-Adorno-Platz 3

D-60629 Frankfurt am Main

www.imfs-frankfurt.de | info@imfs-frankfurt.de 


\title{
Financial Literacy and Savings Account Returns ${ }^{*}$
}

\author{
FLORIAN DEUFLHARD $^{\dagger}$, DIMITRIS GEORGARAKOS ${ }^{\ddagger}$ AND ROMAN INDERST ${ }^{\S}$
}

JANUARY 2014

\begin{abstract}
Savings accounts are owned by most households, but little is known about the performance of households' investments. We create a unique dataset by matching information on individual savings accounts from the DNB Household Survey with market data on account-specific interest rates and characteristics. We document considerable heterogeneity in returns across households, which can be partly explained by financial sophistication. A one-standard deviation increase in financial literacy is associated with a $13 \%$ increase compared to the median interest rate. We isolate the usage of modern technology (online accounts) as one channel through which financial literacy has a positive association with returns.
\end{abstract}

Keywords: Financial literacy; savings accounts; interest rates; household finance JEL Classification: D12, E21, G11, G21

\footnotetext{
*We would like to thank Gabriel Fagan, Luigi Guiso, Arthur Kennickell, Annamaria Lusardi, Maarten van Rooij, and participants at the HFCN meeting at the ECB for helpful comments. We are also grateful to Rob Alessie, Annamaria Lusardi, and Maarten van Rooij for making the data from a special financial literacy module publicly available, to a major Dutch bank for providing interest rate data on savings accounts in the Netherlands, to CentERdata for providing additional information on financial product holdings and bank relationships of DNB survey participants, as well as to SpaarInformatie for providing data on restrictions of Dutch savings accounts. Financial support from IMFS (Frankfurt) is gratefully acknowledged.

${ }^{\dagger}$ Goethe University Frankfurt. Email: florian.deuflhard@ hof.uni-frankfurt.de

$\$$ Goethe University Frankfurt and University of Leicester. Email: georgarakos@hof.uni-frankfurt.de

${ }^{\S}$ Goethe University Frankfurt. Email: inderst@finance.uni-frankfurt.de
} 


\section{Introduction}

Savings accounts typically represent the most common vehicle for household financial investment. In the DNB Household Survey (DHS) savings accounts are owned by $82 \%$ of all Dutch households and make up the largest part of their financial wealth (with an average share of $43 \%) .{ }^{1}$ This contrasts with much lower ownership rates of funds or directly held stocks. ${ }^{2}$ Still, while there exists a large literature documenting how households invest in funds and stocks and how these investments perform, much less is known about savings accounts.

We make use of the fact that the DHS reports bank and account names for each savings account owned by a household member, as well as the respective invested amount. This information allows us to match the DHS with market data on interest rates and other account characteristics. We can thereby calculate for each household a measure of the average return that is earned across all savings accounts owned by its members.

We document considerable heterogeneity in returns across households for such a widely held and virtually riskless asset. To understand such a difference in performance of what seems to be a relatively simple financial product, our study first points to characteristics of the market and products. There is a wide dispersion of interest rates across products even for the same invested amount. A comparison of individual products is also not straightforward, e.g., as accounts differ in the applicable amount thresholds to earn a higher interest rate as well as in

\footnotetext{
${ }^{1}$ The picture is similar for most other Euro area countries according to the recent data from the Household Finance and Consumption Survey (see: http://www.ecb.europa.eu/home/html/researcher_hfcn.en.html).

${ }^{2}$ For a comparison, ownership rates (average shares) are $20 \%(6 \%)$ for funds and only $12 \%$ (3\%) for directly held stocks.
} 
additional restrictions. ${ }^{3}$ The difference in account characteristics, for which we can control, and the variety of offers in the market suggest, in particular, a role for financial sophistication as an explanation for the observed heterogeneity in returns.

This paper is the first, to our knowledge, to show that heterogeneity in returns of a widely held asset such as savings accounts is partly linked to investor financial literacy. We recover measures of financial literacy from a special module of questions that was part of the 2005 wave of the DHS. ${ }^{4}$ Even after accounting for a range of socio-economic characteristics, account characteristics, as well as amount invested, we find that financial literacy has a significant relationship with households' individual returns on savings accounts: a one-standard deviation higher advanced financial literacy is associated with an approximately 33 basis points higher interest rate, which represents an increase of $13 \%$ compared to the median interest rate of $2.5 \%$. We also calculate the gains from moving a household in the lowest literacy quartile to the highest literacy quartile. Applying the estimated gains of literacy to the average savings volume and projecting this over 10 years, total gains in real terms would accumulate to $€ 947$.

Our investigation of products and the market suggests that lack of information may prevent households from securing the highest possible interest rate for the invested amount. ${ }^{5}$ Even at a given bank, households may not choose the most preferable offer. In fact, one such channel that we can isolate is the ability and willingness (or the lack of it) to use a higher interest bearing online account. We also find some evidence to suggest that more literate households might be

\footnotetext{
${ }^{3}$ Notably, this variation is not due to so-called "teaser rates" that are paid when an account is newly opened or when fresh money is transferred, as these rates are not included.

${ }^{4}$ These are the same questions as used in van Rooij et al. $(2011,2012)$.

${ }^{5}$ Several studies cite information/search frictions as a source of price dispersion in retail financial markets net of product differentiation by firms. See, e.g., Hortacsu and Syverson (2004) for S\&P 500 index funds and Stango and Zinman (2013) for credit cards. As a result, firms might have an incentive to add complexity to their pricing structures in order to gain market power (Carlin 2009).
} 
better able to identify accounts across banks that for a given volume and a given set of characteristics offer the highest return. From banks' perspective, lack of knowledge and sophistication are in fact prerequisites to uphold price dispersion across banks as well as price discrimination across accounts.

A common feature of existing studies on households' investment decisions and on financial literacy, as reviewed below, is the difficulty to both isolate the contribution of financial literacy, which requires specific survey questions, and measure asset returns at the same time. Our combined data contain both pieces of information, allowing us to assess the association of financial literacy with savings returns. Importantly, note that the starting point for our matching process of survey data and administrative market data is a nationally representative survey that contains detailed information on all savings accounts held by household members (some of which are held in different banks), as well as on all other financial assets. Moreover, given that our outcome of interest is the applicable interest rate obtained from administrative market data, it is less likely to correlate with literacy through household unobservables such as knowledge about realized returns or reporting bias. Yet, measures of literacy are often subject to measurement error because some of the correct responses are due to guessing (cf. Van Rooij et al. 2011). Our findings point to the latter form of bias, given that we estimate comparable effects of literacy from both IV regressions and non-instrumented regressions that use instead a specification which is more resilient to measurement error.

A number of studies document significant variation in households' financial literacy in various countries. ${ }^{6}$ As savings accounts arguably play an important role in other countries as

\footnotetext{
6 See, for instance, Lusardi and Mitchell (2013) for a recent review of comparable studies in the US as well as Europe, Australia, and Japan. Earlier studies include Bernheim (1998) and Hilgert et al. (2003).
} 
well, we would suggest that our results are likely to be more widely applicable. In fact, to the extent that savings accounts represent the most important financial assets, also the respective welfare implications should concern a large fraction of society in many countries.

As noted above, much of the extant literature on investments has focused on the holdings of stocks and other risky assets. In particular, using the same survey, van Rooij et al. (2011) and van Rooij et al. (2012) find that financial literacy induces stockholding and boosts wealth accumulation, respectively. ${ }^{7}$ Finally, when households earn higher returns on their investments, this provides another explanation, next to differences in savings rates, for differences in retirement savings, which have been explored widely (e.g., Lusardi and Mitchell 2007a, 2007b, 2008; van Rooij et al. 2012).

The rest of the paper is organized as follows. Section 2 presents the data and matching procedure. Section 3 introduces the empirical specifications to uncover the link between financial literacy and returns from savings accounts. Section 4 presents the empirical results, robustness checks, and evaluates implications for consumer welfare. Section 5 concludes.

\section{Data}

\subsection{Household Characteristics and the Use of Savings Accounts}

Our main data source is the DNB Household Survey (DHS) in 2005. The DHS is an annually conducted survey of around 2,000 Dutch households containing extensive information on

${ }^{7}$ Related work shows that cognitive skills such as numeracy (Christelis et al. 2010) and IQ (Grinblatt et al. 2011) positively associate with stockholding (see also Yoong 2011; Arrondel et al. 2012). Moreover, Banks et al. (2010) find that more numerate individuals save more pre- and dissave more post-retirement. Calvet et al. (2009) construct instead a proxy of financial sophistication based on the relationship between households' financial mistakes and education, income, and wealth. Other studies have analyzed the role of literacy for the choice of debt products (e.g., Lusardi and Tufano 2009, Stango and Zinman 2009). For an overview, see Campbell (2006) and Guiso and Sodini (2013). Moreover, several studies have documented how investment mistakes correlate with proxies for financial knowledge such as education (e.g., Calvet et al. 2007; Bilias et al. 2010). 
demographic characteristics, asset and debt holdings, housing, work, health and income, as well as economic and psychological concepts. Variables used from the survey are reported below. The survey is representative of the Dutch population and is conducted via the Internet. ${ }^{8}$ One key feature of the survey is that it asks detailed information on all savings accounts held by a household, including bank and account name, as well as invested volume on each account. ${ }^{9}$ The DHS asks to report invested amounts for each financial asset as of December $31^{\text {st }}$ of the year preceding the interviews.

We supplement the DHS data with information from a special module on financial literacy designed by van Rooij et al. (2011) and conducted over a random sub-sample of the 2005 survey. This module contains a series of questions about financial knowledge addressed to the person in charge of household finances. ${ }^{10}$ Questions from this module have been used to construct an index of basic and an index of advanced financial literacy. ${ }^{11}$ These indices are derived by factor analysis and are normalized to mean zero and standard deviation one (cf. Rooij et al. 2011). Table 1 presents summary statistics of demographics, financial literacy, income, and wealth for the sample later used in the regression analysis. Households exhibit considerable heterogeneity in particular in more advanced financial knowledge. Instead, basic literacy does not vary over a

${ }^{8}$ We use survey weights to make reported statistics representative of the Dutch population. The survey provides equipment to households without Internet access in order to compensate for this form of bias. See Teppa and Vis (2012) for a detailed description of the DHS.

${ }^{9}$ In the regular panel, participants are provided with a list of seven possible answers when asked at which bank they hold each of their savings accounts: ABN Amro, Postbank, Rabobank, ING, Fortis, SNS Bank, and 'Other'. In case participants indicate ownership in the category 'Other', they are further asked to provide the name of the bank. This latter information along with account names held in 'Other' banks is not available in the public version of the dataset, but it has been recovered from additional data that were made available to us by CentERdata. Appendix C provides more details.

${ }^{10}$ Smith et al. (2010) have shown that this person is actually the most influential for households' financial decisions. The remaining socio-demographic characteristics that we take into account refer also to this person, while economic resources are aggregated at the household level.

${ }^{11}$ See Appendix D for the exact wording of these questions. 
significant part of the sample, given that $43 \%$ of households in 2005 manage to answer all basic literacy questions correctly. ${ }^{12}$

Table 2 shows ownership rates and asset ratios for various financial assets from the 2005 survey (i.e., as of December 2004). After checking accounts, which are owned by virtually all households, savings accounts represent the second most prevalent financial asset with an ownership rate of $82 \%$. For a comparison, only $20 \%$ invest in funds and only $12 \%$ hold stocks directly. On average, households invest $43 \%$ of their financial wealth in savings accounts and hold $21 \%$ in checking accounts. Apart from insurances, which account for $12 \%$, all other financial assets have a far lower weight in household portfolios. Thus, in terms of both ownership and financial wealth invested, savings accounts are by far the most important financial asset for Dutch households.

\subsection{Interest Rate Data on Savings Accounts}

We use data on annual interest rates for savings accounts of all Dutch banks from April 2004 to December 2004 provided by a major Dutch financial institution. ${ }^{13}$ The data set covers in total 43 banks and 105 savings accounts. For each savings account, it contains the account name, the bank name, and the weekly interest rate for eleven different amount brackets ranging from $€ 0$ $€ 1,000$ to $€ 45,000$ or more. ${ }^{14}$ In addition, using information from the Dutch Internet comparison website 'SpaarInformatie', we supplement our data with information on various savings account

\footnotetext{
12 The basic literacy questions test for basic numerical skills, thus are more likely to proxy for cognitive ability that typically depreciates at advanced ages (see also van Rooij et al. 2011).

${ }^{13}$ April 2004 is the first month of the administrative data that we have access to.

${ }^{14}$ The exact amount brackets are $€ 0-€ 1,000, € 1,000-€ 2,500, € 2,500-€ 3,500, € 3,500-€ 4,500, € 4,500-€ 7,000$, $€ 7,000$ - €8,000, €8,000 - €9,000, €9,000 - €10,000, €10,000 - €25,000, €25,000 - €45,000 and >€45,000.
} 
restrictions, such as minimum balance requirements or withdrawal limitations. The various restrictions will be used as controls in our empirical specification below.

Table 3 provides summary statistics for the distribution of offered interest rates across different amount brackets. Panel A considers all accounts that are offered in the market. Panel B considers only accounts that were actually used by households in the survey (as of December 2004). As could be expected, accounts typically pay higher rates for larger volumes. Even for a given volume, dispersion is quite high. For example, for savings accounts actually held by at least one survey participant, interest rates for volumes from $€ 2,500$ to $€ 4500$ range from $1.0 \%$ to $4.0 \%$ with an interquartile range of approximately $1.6 \%$, though the latter reduces to $0.9 \%$ for volumes above $€ 45,000$.

We relegate an overview of the various characteristics of individual savings accounts to Table A1 in the Appendix. While these serve mostly as controls, we will also comment on some of these characteristics, notably whether the respective account is an internet account, subsequently in more detail.

\subsection{Data Matching Procedure}

Interest rate data are matched with DHS data as follows. Given the availability of literacy data in the 2005 wave, which reports the holdings of financial assets as of December 31, 2004, we match interest rates for the last week of December 2004 to the DHS data based on bank and account name as well as account volume. Precisely, based on the volume invested by households in each of their individual accounts, we can assign the respective interest rate for the applicable volume bracket. $^{15}$

${ }^{15}$ We recover missing volumes of individual savings accounts following the procedure used by CentERdata for total 
We achieve a full match for $79 \%$ of all accounts held by households in the DHS. We fill in the remaining $21 \%$ of accounts with non-matched interest rates using the reported bank information of each account as described in Appendix C. ${ }^{16}$ For each savings account held by a member of a household, our matched data ultimately contain the invested volume, account name, bank name, and the applicable interest rate.

Based on the matched data, we can calculate across all accounts that a household owns an average interest rate by weighting each account with its respective volume. The interest rate as of the last week of December 2004 is annualized, which is why we refer to it as the (weighted) annualized percentage rate (weighted APR). Table 4 shows the distribution of the weighted APR both for the full sample later used in the regression analysis (Panel A) and across various socioeconomic characteristics and financial literacy (Panel B). The mean is $2.4 \%$ and the median is $2.5 \%$. Dispersion is quite high given an interquartile range of $1.4 \%$ (i.e., 140 basis points). Panel B shows that the weighted APR increases considerably with savings wealth as well as advanced financial literacy, and decreases in age, while education, net income and basic literacy only have a slight impact.

Given that we use below the weighted APR as the core performance measure in our baseline econometric specification, it deserves some further comments. Next to providing us with a single household-level variable, it has the advantage that (relatively) inactive accounts receive little weight. It also summarizes both inter- and intra-bank heterogeneity of all accounts that a household uses. As the survey asks for ownership at the end of 2004, we assigned the (volume-dependent) interest rate of the last week of December 2004. Our results are, however,

savings volumes as described in Appendix C.

${ }^{16}$ We discuss robustness of our results to this procedure in Section 4. 
robust when we use, instead, a (geometrically) weighted interest rate for each account over all weeks in $2004 .^{17}$

\section{Econometric Specification}

The preceding description of the market for savings accounts suggests various channels through which households can fail to obtain the highest possible return on their savings account(s). First, while banks offer different interest rates even for accounts with similar characteristics, lack of information may prevent households from shopping successfully for the highest interest account. Second, even at a given bank, households may not choose the most preferable account for the amount that they save. Finally, even for a given set of own savings accounts, households may fail to allocate their savings to the highest interest account, potentially foregoing higher interest for larger volumes. While we cannot completely disentangle these different channels, we provide some evidence for their relative importance in Section 4.

Our main aim is to provide an estimate of the relationship between financial literacy and savings account returns. To that effect, we estimate the following linear specification:

$$
r_{h}=\beta_{1} \text { FinLit }_{h}+\beta_{2} X_{h}+\beta_{3} W_{h}+\beta_{4} Z_{h}+\varepsilon_{h}
$$

where $r_{h}$ denotes the weighted APR across all accounts that each household $h$ owns. The covariate of interest is FinLit ${ }_{h}$, which represents the advanced financial literacy index for each household. The vector $X_{h}$ contains a set of household demographics including age, education, an

17 Precisely, for 2004 we can use interest data from April 2004 to December 2004. Interest rate changes are relatively infrequent in this period. 
index of basic literacy ${ }^{18}$, gender, marital status, and the number of children as well as occupation status. We also take into account household resources in a quite flexible way. That is, the vector $W_{h}$ consists of net income, total savings account volume, net financial (non-savings account) wealth, and net real wealth, each of them controlled via dummies denoting quartiles of the respective distributions. ${ }^{19}$ Moreover, we include region dummies to take into account any relevant regional disparities, e.g., in density of bank branches or in local employment conditions.

In addition, we condition our specification on account characteristics and bank fixed effects, comprised in $Z_{h}$. To account for the former, we include a set of dummies denoting various account restrictions (e.g., minimum balance requirements, withdrawal limitations, additional fees, or salary accounts). These dummies take the value one if at least one of the savings accounts in a household is subject to the restriction in question. We further include balance-weighted bank fixed effects accounting for average APR differences across banks, e.g., due to differences in product offerings, advertising spending, or customers' evaluation of bank services. ${ }^{20}$

We also examine the sensitivity of our findings from the baseline specification in Eq. (1) to a specification that allows us to control for characteristics of savings accounts directly, instead of

18 As previously discussed, basic literacy should rather proxy for cognitive skills and is in fact invariant for a significant part of the sample that manages to answer correctly all basic literacy questions.

19 Net financial wealth includes checking accounts, deposit books, savings certificates, bonds, stocks, funds, options, employer-sponsored savings plans, insurances, and other financial wealth minus total financial debt. For further details on the specific subcomponents see the notes in Table 2. For a careful definition of household net income see section 1.3 (Aggregate data on income) in the documentation of the DNB Household Survey 2005 available at http://cdata3.uvt.nl/dhs/files/CodebookWave2005English.pdf. We use the same definition of net income, but count it as missing only if all subcomponents are missing. See Appendix D for details. In the robustness section, we also present estimation results from a specification that does not condition on savings account quartiles that are likely endogenous. As we show, this exclusion leaves our key estimates unaffected.

${ }^{20}$ Including dummies denoting whether at least one of the accounts in a household is held at a particular bank, leaves the later results unaffected. 
aggregating them to the household level. To that effect, we estimate the following, account-level specification:

$$
r_{h s}=\beta_{1} \text { FinLit }_{h}+\beta_{2} X_{h}+\beta_{3} V_{h s}+\beta_{4} Z_{s}+\varepsilon_{h s}
$$

where $r_{h s}$ represents the interest rate earned on account $s$ held by household $h$. As in the previous specification, FinLit and $_{h}$ denote the advanced financial literacy index and a number of socioeconomic characteristics of household $h$. In contrast to the household-level specification, we now replace net financial and net real wealth by a set of nine dummies, contained in $V_{h s}$, which take the value one if the account volume falls into one of the previously discussed amount brackets over which interest rates can vary and are zero otherwise. ${ }^{21}$ Last, we include account restrictions and bank fixed effects specific to each account in $Z_{s}$.

The specification in Eq. (2) treats each account held individually. Thus, it closes down one channel through which financial literacy could affect households' returns, namely to allocate total savings wealth to the highest interest account within a household. Instead, this specification allows us to assess the importance of the other two aforementioned possible mechanisms at work, namely shopping for the highest interest account within and across banks.

When estimating the baseline specification in Eq. (1) as well as the account-level specification in Eq. (2), one should take into account the potential endogeneity of financial literacy. This has been a common empirical challenge for studies using survey data to examine the effect of literacy on various economic outcomes. In our set-up, it should be noted that the

21 As in Table 3, we group together three amount brackets from $€ 7,000$ to $€ 10,000$ due to too few observations in these categories and no account reaching a new volume threshold within this range. 
outcome of interest is the applicable interest rate that is obtained from administrative market data. Thus, it is less likely to correlate with literacy through household-specific unobserved factors such as knowledge about realized returns or reporting bias. Nevertheless, measurement error in the advanced financial literacy index remains a valid concern, given that some of the correct responses are likely to result from guessing (cf. van Rooij et al. 2011). In this case, our estimated effect of literacy from OLS will be downward biased.

One standard way to address this potential endogeneity issue is to use instrumental variable estimation. A valid instrument should exhibit meaningful correlation with advanced financial literacy and affect the interest rate only through this channel and not through other unobserved factors.

We employ the instruments from two earlier studies that use the same financial literacy data. Building on van Rooij et al. (2011), we use the financial experience of the oldest sibling as an instrument for advanced financial literacy. ${ }^{22}$ The authors argue in favor of a learning channel through which respondents tend to become more literate from the negative experiences of their siblings, which is consistent with the negative correlation obtained in our (and their) first stage regression. In addition, following van Rooij et al. (2012), we use as a second instrument the economics education of the respondent. ${ }^{23}$ Note that in our specifications, we control for contemporaneous net financial and net real wealth, taking explicitly into account a potential alternative channel through which past economics education can influence current investment choices.

\footnotetext{
${ }^{22}$ Respondents were asked to indicate whether the financial situation of the oldest sibling is better, the same, or worse compared to their own financial situation.

${ }^{23}$ Specifically, respondents were asked how much of their past education was devoted to economics (i.e., 'a lot', 'some', 'little', and 'hardly at all').
} 
As an alternative way to deal with the likely measurement error of literacy, we have estimated a more flexible specification that controls for quartiles of literacy and is thus more resilient to this measurement issue. Results from this specification (presented in the robustness section) are broadly consistent to those derived under the instrumental variable estimation of the baseline model.

\section{Results}

In what follows, we first present results from our baseline specification in Eq. (1) at the household level, followed by results from the specification in Eq. (2) at the account level. Subsequently, we discuss a number of robustness checks we have performed. Finally, we evaluate possible implications for household welfare.

\subsection{Household-Level Baseline Results}

We first examine the relationship between financial literacy and the weighted APR of each household. Table 5 shows OLS and IV estimates and their associated standard errors that are robust to heteroskedasticity. ${ }^{24}$ The first specification, OLS(1), conditions on advanced literacy as well as on various socio-economic household characteristics discussed above. Note that this specification follows the baseline specification that is estimated in van Rooij et al. (2011), albeit the dependent variable in our set up is the weighted APR (instead of a stock ownership dummy). The second specification, IV(1), instruments for advanced financial literacy using as instruments the financial situation of the oldest sibling and the economics education of the respondent. In the

${ }^{24}$ In all IV-specifications, we use two-stage least squares. 
third specification, OLS(2), we add account characteristics and bank fixed effects, while its IV counterpart is provided by the fourth specification, IV(2).

In both IV-specifications, the F-statistics from the first stage regressions are slightly above the (rule of thumb) threshold of 10 and the two instruments exhibit meaningful correlations with the advanced literacy index (results from the first stage regressions are shown in Table B1, Appendix B). Given that we employ two instruments for one potentially endogenous covariate, one can test for their statistical validity on the basis of a test for over-identifying restrictions. According to the Hansen J-test (reported at the bottom of the table), we fail to reject the null hypothesis that the instruments are jointly valid (p-values: .51 and .21$){ }^{25}$

Adding account and bank fixed effects to the first specification, as expected, considerably increases the fit of the model. In both OLS specifications, the coefficient of advanced financial literacy is statistically significant ( $\mathrm{p}$-value $<.01)$ and shows a positive association with the weighted APR. The corresponding IV estimates remain statistically significant and suggest a relatively stronger relationship. An assumed one-standard deviation increase in advanced financial literacy in the full specification implies a 33 basis points increase in the weighted APR. This effect, estimated net of socio-economic characteristics, account characteristics, and bank fixed effects, is nontrivial, given that it corresponds to $13 \%$ of the median interest rate in our sample.

\footnotetext{
25 Moreover, we have used the method proposed by Lewbel (2012) and generated additional instruments as functions of the other covariates in the baseline model, under the assumption that they are uncorrelated with the covariance of the heteroskedastic errors. This allows us to test for the exogeneity of both external instruments we have employed. The p-values from the estimated C-statistics (calculated as the difference in Sargan-Hansen statistics of the model with the transformed instruments only and the one with both the transformed and the external instruments), are .66 for IV(1) and 0.28 for IV(2), suggesting in favor of exogeneity of the two external instruments in both specifications.
} 
Regarding other covariates, we estimate a strong negative association of the weighted APR with age. For example, respondents above sixty earn about 47 basis points less on average as compared to the base category of young adults below thirty. This is likely to suggest a significant role for age-of-account-effects given that the age of an account and respondents' age are likely to be highly correlated.

Not surprisingly, savings wealth is correlated with the weighted APR, especially in the two higher quartiles. Respondents in the highest savings wealth quartile earn on average 51 basis points more as compared to the bottom quartile. This follows directly from the fact that accounts frequently pay higher interest rates for larger volumes. As we show in the robustness section, our estimated effects of literacy remain unaffected, when we do not take into account savings account volume that is likely endogenous. Apart from advanced literacy, age, and savings account wealth, none of the remaining household characteristics play any significant role.

\subsection{Account-Level Regressions}

In all account-level regressions, we exclude accounts with very low volumes (i.e., below $€ 50) .{ }^{26}$ Table 6 presents results from the account-level regressions as in Eq. (2). Given that financial literacy and other socio-economic characteristics, used as controls in this specification, do not vary across accounts owned by the same household, we cluster standard errors at the household level.

The first specification, OLS(1), takes into account socio-economic characteristics and account volume dummies, while in the third specification, OLS(2), we add account

\footnotetext{
${ }^{26}$ These accounts are likely to be inactive and, due to their low volume, hardly affect the weighted APR at the household level. This concerns around $6.8 \%$ of the accounts in the account-level sample. When using the full sample of accounts, the estimated effect of literacy is still statistically significant, though of slightly smaller magnitude.
} 
characteristics and bank fixed effects. The second and the fourth specification, IV(1) and $\operatorname{IV}(2)$, show results from the IV counterparts of the two OLS specifications. Results from the corresponding first stage regressions (shown in Table B2, Appendix B) as well as tests for instrument validity are highly comparable to those obtained for the household-level baseline specification.

The estimated effects of advanced literacy at the account level are quite comparable to our previous findings in terms of significance and magnitude, both in the OLS and IV specifications. In the fully specified IV regression, the estimate of advanced financial literacy is 32 basis points and statistically significant at the $1 \%$-level. The account volume dummies show, as expected, a progressively stronger association with a higher interest rate. The majority of account characteristics are also highly significant with the expected signs, e.g., accounts with more restrictions pay on average higher interest rates. ${ }^{27}$ Even after accounting for these characteristics, as well as bank fixed effects, financial literacy is still significantly associated with the APR.

Recall, that the account-level specification precludes the possibility to reallocate funds to the highest interest account within household as a channel for financial literacy to influence the APR, while such a mechanism could be at work in the household-level regressions. The comparable effect of financial literacy in both specifications suggests that this channel is likely to be of limited importance. This is supported by the fact that, while the median number of owned accounts is two, households in the DHS tend to concentrate their savings mostly in one account that typically earns the highest interest. ${ }^{28}$

\footnotetext{
27 The only exception is the dummy for additional fees, which displays a negative sign. It should be noted, however, that the estimated net effect of each account characteristic may be hard to interpret, given that many of these restrictions typically co-exist.

${ }^{28}$ For instance, $70 \%$ of households allocate more than $80 \%$ to a single account.
} 


\subsection{Online Banking Usage}

One possible mechanism through which literacy could positively associate with APRs is through households' ability to choose the highest interest savings account in a given bank. Internet accounts are fully managed online with limited bank service and in return typically offer higher interest rates.

We now re-estimate our two previous main specifications by adding an internet account dummy. ${ }^{29}$ As before, it takes the value one if a household owns at least one internet account in Eq. (1) or if the account is an internet account in Eq. (2). Table 7 shows the results from household- (Panel A) and account-level (Panel B) regressions. In both cases, the internet account dummy shows a strong positive association with the APR. For example, in the account-level regression, after accounting for various account restrictions and bank fixed effects, the estimated impact of having an internet-managed account exceeds 120 basis points.

The implied effect of literacy in both household-level and account-level regressions is still statistically significant, albeit quantitatively smaller by almost one third. This suggests that at least part of the effect of advanced financial literacy on the APR derives from familiarity with new technologies and the willingness and ability to use self-managed online banking.

The remaining effects of advanced literacy that we estimate are net of various household and account characteristics, internet-managed accounts, as well as fixed differences across banks. Nonetheless, this still leaves room for financial literacy to play a role as more literate households might be better able to identify accounts across banks that for a given volume and a given set of characteristics offer the highest return (i.e., above average differences in returns that are

\footnotetext{
${ }^{29}$ We obtain similar results when using self-reported online banking use, instead, which is asked in the DHS, as this is highly correlated with having an internet account.
} 
absorbed by bank fixed effects). Thus, these findings appear consistent with the first mechanism outlined above, namely the limited ability of low literacy households to choose accounts across different banks that - for a given configuration of volume and characteristics - offer the highest returns.

\subsection{Robustness Checks}

We now examine the robustness of our results regarding our baseline specification in Eq. (1) at the household level. Results from corresponding robustness checks for the account levelspecification in Eq. (2) show a similar picture and are not reported for brevity. Table 8 summarizes results from a number of robustness checks at the household level. Panel A shows results from a specification that does not include savings volume quartiles, which are potentially endogenous. This exclusion leaves our advanced financial literacy estimate unaffected.

Panel B shows estimates from a specification that uses financial literacy quartiles instead of a continuous index. Households in the top advanced literacy quartile earn on average 29 basis points more interest as compared to their counterparts in the lowest literacy quartile, controlling for wealth, income, demographics, and account characteristics (OLS(2)) ${ }^{30}$ This specification is more robust to measurement error in the financial literacy index and yields results that are broadly in line with those estimated under the IV-specification in Table 5. This suggests that the financial literacy index may indeed suffer from measurement error that is taken into account by the instrumental variable estimation used for the continuous literacy index.

Panel $\mathrm{C}$ shows average marginal effects from an ordered probit using interest rate quartiles as the dependent variable and the same set of controls as in Eq. (1). Increasing advanced

\footnotetext{
${ }^{30}$ Obviously, we cannot easily instrument for advanced financial literacy when using quartiles due to the number of endogenous covariates.
} 
financial literacy by one standard deviation increases the probability of being in the top interest rate quartile by 5.7 percentage points, corresponding to a $22.8 \%$ increase in the unconditional probability of being in that category. Panel D shows average marginal effects from the same ordered probit, this time controlling for literacy quartiles as well. Households in the highest literacy quartile are 14.8 percentage points more likely to be in the top interest rate quartile as compared to households in the lowest literacy quartile, corresponding to a 59.2\% increase in the unconditional probability of being in that category. Taken together, results from the ordered probit suggest that our findings are resilient to any outliers in APRs.

We have also accounted for a number of factors that may influence the weighted APR. Given that these additional controls have some missing values that reduce our estimation sample by about $15 \%$ to $20 \%$ in each case, we add one factor at a time to our main household-level specification. ${ }^{31}$ First, we include a measure of risk aversion from the DHS as used in a similar robustness check by van Rooij et al. (2011) to account for differences in risk preferences. Based on two gambles presented to survey participants in the DHS, this measure can take five possible outcomes from low to high risk aversion (including one category for those who answered 'do not know'). The inclusion of this measure of risk aversion (that is itself insignificant) in our specification does not affect our estimate of advanced financial literacy.

Second, while we control for employment status in our main specification, households frequently exposed to transitory income shocks, might on average hold more liquid accounts with lower APRs. To this end, we include a dummy indicating whether households' last year's income was unusually low. The inclusion of this additional variable, however, leaves our key estimate unaffected. Third, we also added hours worked to our specification to proxy for

${ }^{31}$ See Appendix D for the exact wording of these questions. 
opportunity costs of shopping for higher rates. This variable has no significant impact on the APR and our estimates for literacy remain again unaffected.

Moreover, recall that in the account-level specification, we assign to each account held by any member of non-single households the financial literacy of the household's financial respondent. This might be problematic if household members differ significantly in their degree of literacy. To this end, we re-estimate the specification in Eq. (2) using this time only accounts owned by the financial respondent. Given that a significant fraction of accounts is held by this household member, our sample reduces only by approximately $15 \%$. Our estimates of literacy remain highly significant at $1 \%$-level and slightly increase with an estimated coefficient of 35 basis points in the IV-specification.

Finally, we have re-estimated our account-level specification, using only those accounts with matched interest rate. As a result, our sample reduces by $21 \%$ as we exclude accounts for which we had to follow the process described in Appendix $\mathrm{C}$ in order to recover the interest rate. Again, our estimates of literacy remain highly significant at $1 \%$-level with an estimated coefficient of 37 basis points in the IV-specification.

\subsection{Welfare Implications}

Lastly, we attempt to quantify the implications of our key findings for household welfare. To that effect, we estimate how much more an investor in the lowest literacy quartile could have earned today on her savings accounts when moved to the highest literacy quartile (other things equal). ${ }^{32}$

\footnotetext{
${ }^{32}$ For our calculation, we assume more narrowly that such an increase in financial literacy takes place for a single household only. If, for instance, a publicly sponsored program lifts financial literacy for a larger fraction of households, however, our calculation represents only a partial equilibrium analysis in the following sense. Presently, as noted above, price differentiation across banks but also across accounts at a given bank seems to be possible as consumers are sophisticated to a different degree. When more consumers become literate in this sense, there is less
} 
We have to make several assumptions in order to perform such a counterfactual exercise. We consider a 10-year time horizon and suppose that earned returns are reinvested. For each year, we use as the baseline rate the median interest rate of households in the first literacy quartile, which is $2.3 \%$. Using our preferred estimate from the IV(2) specification in Table 5, we calculate that a household, moved from the lowest to the highest literacy quartile, would earn 43 basis points more on average. ${ }^{33}$ We then apply this extra return to the average household savings volume. To be conservative, we assume that additional deposits invested by households as a percentage of total savings wealth over one year grow only by the annual inflation rate. ${ }^{34}$ In this set-up, losses accumulate to $€ 947$ in real terms over 10 years or $5.4 \%$ of the initially invested average amount.

\section{Concluding Remarks}

We have constructed a unique data set by matching the 2005 DNB Household Survey, which includes detailed information on individual savings accounts, various socio-economic characteristics and financial literacy, with interest rate data on savings accounts from an administrative source, based on bank names, account names, and account volume.

While savings accounts represent a relatively simple investment, say compared to direct stock holdings or retirement funds, we first document considerable variation in interest rates in the market, as well as in actually used accounts, and a large heterogeneity in accounts across and

scope for such differentiation. In equilibrium, banks would react by adjusting their offers. One possibility, which can be supported by a formal analysis, is that as more households become willing and able to choose the best offer, offers would become more attractive across the board, in which case the general equilibrium effect of a financial literacy program would further enhance the benefits to, in particular, (newly) literate households.

${ }^{33}$ In our calculations, we use summary statistics from the full sample in 2005 for both total savings volume and financial literacy.

${ }^{34}$ This simplifies matters in the sense that additional deposits and inflation cancel out in the calculation of cumulative losses. 
within banks. In this environment, more financially literate investors earn higher savings returns on average, controlling for demographics, account volume, and various account characteristics. We isolate one channel through which literacy positively affects interest rates, namely familiarity with new technologies (online banking usage). We also find some evidence to suggest that more literate households are better able to identify higher interest bearing accounts across banks.

Unlike stocks and funds, savings accounts are held by the overwhelming majority of households and have the highest share in household financial wealth on average. Thus, even a limited association between literacy and savings returns can have non-trivial welfare implications. From a policy perspective, making households aware about the likely benefits of a more efficient management of their savings products can have immediate effects on household welfare.

Our findings may encourage more research in order to understand household heterogeneity in seemingly 'simple' and widely held financial assets. In this respect, it may be worth extending our research to countries with a varying degree of market competitiveness and product complexity as well as less financially literate populations. Finally, we show significant variation in returns of a safe asset, which can be partly explained by household attributes, such as financial sophistication. In contrast, in standard lifecycle models of optimal portfolio choice returns from a safe asset are typically fixed over all investors. Allowing for heterogeneity in safe returns might offer another interesting avenue for future research. 


\section{References}

Arrondel, L., Debbich, M., Savignac, F., 2012. Stockholding and financial literacy in the French population. International Journal of Social Sciences and Humanity Studies 4, 1309-8063.

Banks, J., O’Dea, C., Oldfield, Z., 2010. Cognitive function, numeracy and retirement saving trajectories. The Economic Journal 120, F381-F410.

Bernheim, D. B., 1998. Financial illiteracy, education, and retirement saving. In: Mitchell, O. S., Schieber, S. J. (eds.), Living with Defined Contribution Pensions, University of Pennsylvania Press, Philadelphia.

Bilias, Y., Georgarakos, D., Haliassos, M., 2010. Portfolio inertia and stock market fluctuations. Journal of Money, Credit and Banking 42, 715-742.

Calvet, L. E., Campbell, J. Y., Sodini, P., 2007. Down or out: Assessing the welfare costs of household investment mistakes. Journal of Political Economy 115, 707-747.

Calvet, L. E., Campbell, J. Y., Sodini, P., 2009. Measuring the financial sophistication of households. The American Economic Review 99, 393-398.

Campbell, J. Y., 2006. Household finance. The Journal of Finance 61, 1553-1604.

Carlin, B. I., 2009. Strategic price complexity in retail financial markets. Journal of Financial Economics 91, 278287.

Christelis, D., Jappelli, T., Padula, M., 2010. Cognitive abilities and portfolio choice. European Economic Review $54,18-38$.

Grinblatt, M., Keloharju, M., Linnainmaa, J., 2011. IQ and stock market participation. The Journal of Finance 66, $2121-2164$.

Guiso, L., Sodini, P., 2013. Chapter 21 - Household finance: An emerging field. Elsevier, vol. 2, Part B of Handbook of the Economics of Finance, pp. 1397 - 1532.

Hilgert, M. A., Hogarth, J. M., Beverly, S. G., 2003. Household financial management: The connection between knowledge and behavior. Federal Reserve Bulletin 89, 309-322.

Hortaçsu, A., Syverson, C., 2004. Product differentiation, search costs, and competition in the mutual fund industry: A case study of s\&p 500 index funds. The Quarterly Journal of Economics 119, 403-456. 
Lewbel, A., 2012. Using heteroscedasticity to identify and estimate mismeasured and endogenous regressor models. Journal of Business \& Economic Statistics 30, 67-80.

Lusardi, A., Mitchell, O. S., 2007a. Baby boomer retirement security: The roles of planning, financial literacy, and housing wealth. Journal of Monetary Economics 54, 205-224.

Lusardi, A., Mitchell, O. S., 2007b. Financial literacy and retirement preparedness: Evidence and implications for financial education. Business Economics 42, 35-44.

Lusardi, A., Mitchell, O. S., 2008. Planning and financial literacy: How do women fare? The American Economic Review 98, 413-417.

Lusardi, A., Mitchell, O. S., 2013. The economic importance of financial literacy: Theory and evidence. Working Paper 18952, National Bureau of Economic Research.

Lusardi, A., Tufano, P., 2009. Debt literacy, financial experiences, and overindebtedness. Working Paper 14808, National Bureau of Economic Research.

Smith, J. P., McArdle, J. J., Willis, R., 2010. Financial decision making and cognition in a family context. The Economic Journal 120, F363-F380.

Stango, V., Zinman, J., 2009. Exponential growth bias and household finance. The Journal of Finance 64, 28072849.

Stango, V., Zinman, J., 2013. Borrowing high vs. borrowing higher: Sources and consequences of dispersion in individual borrowing costs. Working Paper 19069, National Bureau of Economic Research.

Teppa, F., Vis, C., 2012. The Centerpanel and the DNB household survey: Methodological aspects. Tech. rep., Netherlands Central Bank, Research Department.

van Rooij, M., Lusardi, A., Alessie, R., 2011. Financial literacy and stock market participation. Journal of Financial Economics 101, 449-472.

van Rooij, M., Lusardi, A., Alessie, R., 2012. Financial literacy, retirement planning and household wealth. The Economic Journal 122, 449-478.

Yoong, J., 2011. Financial illiteracy and stock market participation: Evidence from the rand American life panel. In: Mitchell, O. S., Lusardi, A. (eds.), Financial Literacy: Implications for Retirement Security and the Financial Marketplace, Oxford University Press, Oxford. 
Table 1

Summary statistics household-level variables.

The sample consists of those households later used in the regressions analysis. See Appendix D for a careful definition of all variables. The data are from the DNB Household Survey 2005. All statistics use sample weights.

\begin{tabular}{|c|c|c|c|c|c|c|}
\hline Variable & Mean & Std. Dev. & 25 th pet. & Median & 75th pet. & $\mathrm{N}$ \\
\hline Number of accounts & 1.84 & 1.17 & 1.00 & 2.00 & 2.00 & 888 \\
\hline Total savings account volume & 18,679 & 42,312 & 1,429 & 6,741 & 20,433 & 888 \\
\hline Net income & 27,862 & 41,910 & 16,568 & 24,286 & 35,033 & 888 \\
\hline Net financial wealth & 41,212 & 116,703 & 2,692 & 15,154 & 40,250 & 888 \\
\hline Net real wealth & 123,774 & 221,232 & 2,000 & 26,000 & 194,914 & 888 \\
\hline Advanced Financial Literacy & 0.06 & 0.97 & -0.29 & 0.45 & 0.77 & 888 \\
\hline Basic Financial Literacy & 0.08 & 1.13 & -0.15 & 0.49 & 0.79 & 888 \\
\hline Age & 49.82 & 15.63 & 36.00 & 49.00 & 62.00 & 888 \\
\hline Less than high school & 0.28 & 0.45 & 0.00 & 0.00 & 1.00 & 888 \\
\hline High school & 0.34 & 0.47 & 0.00 & 0.00 & 1.00 & 888 \\
\hline College & 0.38 & 0.49 & 0.00 & 0.00 & 1.00 & 888 \\
\hline Male & 0.55 & 0.50 & 0.00 & 1.00 & 1.00 & 888 \\
\hline Couple & 0.64 & 0.48 & 0.00 & 1.00 & 1.00 & 888 \\
\hline Number of children & 0.60 & 1.00 & 0.00 & 0.00 & 1.00 & 888 \\
\hline Other employment & 0.22 & 0.41 & 0.00 & 0.00 & 0.00 & 888 \\
\hline Employed & 0.50 & 0.50 & 0.00 & 1.00 & 1.00 & 888 \\
\hline Self-employed & 0.04 & 0.20 & 0.00 & 0.00 & 0.00 & 888 \\
\hline Unemployed & 0.02 & 0.15 & 0.00 & 0.00 & 0.00 & 888 \\
\hline Retired & 0.22 & 0.41 & 0.00 & 0.00 & 0.00 & 888 \\
\hline
\end{tabular}


Table 2

Balance sheet of Dutch households.

This table shows asset ownership rates, asset ratios of Dutch households, $25^{\text {th }}$ percentile, median, and $75^{\text {th }}$ percentile holdings. Percentile and median holdings are conditional, whereas asset ratios are unconditional on ownership of the specific asset class. Because of that, financial assets do not sum up to financial wealth. All amounts are in Euros. Stocks comprise stocks and stocks from substantial holdings. Funds include mutual as well as growth funds. Insurances contain SinglePremium Annuity and Savings or Endowment Insurance Policies. Other financial wealth includes money lent out to family/friends and other savings. Home equity contains the value of the first and second house plus other real estate. Durable goods comprise the value of cars, motorbikes, boats, and caravans. The data are from the DNB Household Survey in 2005. All statistics use sample weights.

\begin{tabular}{|c|c|c|c|c|c|c|}
\hline Asset Category & Ownership Rate & Mean Holdings & Asset Ratio & $\begin{array}{l}25^{\text {th }} \text { pet. } \\
\text { Holdings }\end{array}$ & $\begin{array}{l}\text { Median } \\
\text { Holdings }\end{array}$ & $\begin{array}{l}75^{\text {th }} \text { pet. } \\
\text { Holdings }\end{array}$ \\
\hline & & & $\begin{array}{r}\text { in } \% \text { of } \\
\text { financial wealth }\end{array}$ & & & \\
\hline Checking accounts & $95.8 \%$ & 3,251 & $21.2 \%$ & 625 & 1,600 & 3,300 \\
\hline Savings / deposit acc. & $82.4 \%$ & 17,641 & $42.9 \%$ & 1,300 & 6,220 & 20,000 \\
\hline Deposit books & $7.5 \%$ & 4,372 & $2.3 \%$ & 356 & 1,199 & 4,532 \\
\hline Savings certificates & $2.1 \%$ & 4,068 & $0.4 \%$ & 600 & 1,163 & 4,538 \\
\hline Bonds & $4.6 \%$ & 48,880 & $1.0 \%$ & 2,680 & 8,000 & 37,500 \\
\hline Stocks & $12.3 \%$ & 28,404 & $3.1 \%$ & 1,810 & 5,876 & 22,246 \\
\hline Funds & $20.4 \%$ & 27,147 & $5.9 \%$ & 2,766 & 8,600 & 22,000 \\
\hline Options & $1.2 \%$ & 2,190 & $0.1 \%$ & 200 & 1,000 & 3,177 \\
\hline Empl.-spons. savings plan & $38.4 \%$ & 3,787 & $8.4 \%$ & 722 & 2,026 & 4,000 \\
\hline Insurances & $30.8 \%$ & 23,248 & $11.6 \%$ & 1,259 & 7,008 & 20,360 \\
\hline \multirow[t]{2}{*}{ Other financial wealth } & $11.8 \%$ & 22,400 & $3.1 \%$ & 905 & 3,500 & 10,000 \\
\hline & & & $\begin{array}{r}\text { in } \% \text { of total } \\
\text { wealth }\end{array}$ & & & \\
\hline Financial wealth & $97.0 \%$ & 41,564 & $42.5 \%$ & 3,585 & 13,610 & 38,402 \\
\hline Home equity and other real estate & $49.7 \%$ & 280,857 & $47.1 \%$ & 180,000 & 225,000 & 320,000 \\
\hline Business equity & $3.4 \%$ & 95,814 & $1.4 \%$ & 25,000 & 25,000 & 35,000 \\
\hline Durable goods & $77.1 \%$ & 9,922 & $14.4 \%$ & 2,750 & 6,500 & 12,764 \\
\hline
\end{tabular}


Table 3

Distribution of interest rates across amount brackets.

This table shows the distribution of the account-level APR across nine amount brackets. Panel A shows the distribution of offered accounts by banks as in the interest rate data set. Panel B shows the same for accounts actually used by households in the DHS. We group together three amount brackets from $€ 7,000$ to $€ 10,000$ due to too few observations in the respective categories for used accounts and no offered account reaching a new volume threshold within this range. The data are from the market data on interest rates (Panel A) and the matched DNB Household Survey as of the last week of December 2004.

Panel A: Offered accounts

\begin{tabular}{|c|c|c|c|c|c|c|c|c|}
\hline Amount & Mean & Std. Dev. & Min. & $25^{\text {th }}$ pct. & Median & $75^{\text {th }}$ pct. & Max. & $\mathrm{N}$ \\
\hline$€ 0-€ 1,000$ & 2.38 & 0.87 & 0.25 & 1.75 & 2.50 & 3.05 & 4.00 & 92 \\
\hline$€ 1,000-€ 2,500$ & 2.42 & 0.84 & 0.25 & 1.75 & 2.50 & 3.10 & 4.00 & 95 \\
\hline$€ 2,500-€ 3,500$ & 2.44 & 0.82 & 0.25 & 1.75 & 2.50 & 3.10 & 4.00 & 95 \\
\hline$€ 3,500-€ 4,500$ & 2.44 & 0.82 & 0.25 & 1.75 & 2.50 & 3.10 & 4.00 & 95 \\
\hline$€ 4,500-€ 7,000$ & 2.48 & 0.79 & 0.25 & 2.00 & 2.50 & 3.10 & 4.00 & 95 \\
\hline$€ 7,000-€ 10,000$ & 2.56 & 0.73 & 0.50 & 2.00 & 2.50 & 3.10 & 4.00 & 97 \\
\hline$€ 10,000-€ 25,000$ & 2.59 & 0.68 & 1.00 & 2.00 & 2.60 & 3.10 & 4.00 & 98 \\
\hline$€ 25,000-€ 45,000$ & 2.64 & 0.63 & 1.00 & 2.20 & 2.67 & 3.10 & 4.00 & 98 \\
\hline$>€ 45,000$ & 2.65 & 0.63 & 1.00 & 2.20 & 2.70 & 3.10 & 4.00 & 98 \\
\hline
\end{tabular}

Panel B: Used accounts

\begin{tabular}{|c|c|c|c|c|c|c|c|c|}
\hline Amount & Mean & Std. Dev. & Min. & $25^{\text {th }}$ pct. & Median & $75^{\text {th }}$ pct. & Max. & $\mathrm{N}$ \\
\hline$€ 0-€ 1,000$ & 2.09 & 0.95 & 1.00 & 1.10 & 2.00 & 3.10 & 4.00 & 716 \\
\hline$€ 1,000-€ 2,500$ & 2.20 & 0.94 & 1.00 & 1.10 & 2.45 & 3.10 & 4.00 & 338 \\
\hline$€ 2,500-€ 3,500$ & 2.24 & 0.88 & 1.00 & 1.35 & 2.40 & 3.00 & 4.00 & 146 \\
\hline$€ 3,500-€ 4,500$ & 2.34 & 0.85 & 1.00 & 1.55 & 2.50 & 3.10 & 4.00 & 119 \\
\hline$€ 4,500-€ 7,000$ & 2.52 & 0.80 & 1.00 & 1.95 & 2.50 & 3.25 & 4.00 & 184 \\
\hline$€ 7,000-€ 10,000$ & 2.55 & 0.76 & 1.00 & 2.30 & 2.50 & 3.10 & 4.00 & 152 \\
\hline$€ 10,000-€ 25,000$ & 2.56 & 0.73 & 1.00 & 2.15 & 2.70 & 3.30 & 4.00 & 352 \\
\hline$€ 25,000-€ 45,000$ & 2.63 & 0.62 & 1.00 & 2.15 & 2.50 & 3.30 & 3.50 & 139 \\
\hline$>€ 45,000$ & 2.80 & 0.51 & 1.00 & 2.40 & 3.00 & 3.30 & 3.50 & 91 \\
\hline
\end{tabular}




\section{Table 4}

Distribution of weighted APR.

This table shows the distribution of the weighted APR over the full sample later used in the regression analysis (Panel A) and across various household-level variables (Panel B). The data are from the matched DNB Household Survey in 2005. All statistics use sample weights.

\begin{tabular}{|c|c|c|c|c|c|}
\hline Mean & Std. Dev. & 25 th pct. & Median & 75th pct. & $\mathrm{N}$ \\
\hline 2.37 & 0.77 & 1.60 & 2.50 & 3.00 & 888 \\
\hline \multicolumn{3}{|l|}{ Education } & \multicolumn{3}{|l|}{ Age } \\
\hline \multicolumn{2}{|c|}{ Less than high school } & 2.31 & \multicolumn{2}{|l|}{$18-30$ years } & 2.64 \\
\hline \multicolumn{2}{|c|}{ High school } & 2.37 & \multicolumn{2}{|l|}{$31-40$ years } & 2.36 \\
\hline \multirow{3}{*}{ College } & & 2.42 & \multicolumn{2}{|l|}{$41-50$ years } & 2.28 \\
\hline & & & \multicolumn{2}{|c|}{$51-60$ years } & 2.36 \\
\hline & & & \multicolumn{2}{|c|}{61 years and older } & 2.33 \\
\hline \multicolumn{3}{|l|}{ Gender } & \multicolumn{3}{|l|}{ Married } \\
\hline \multicolumn{2}{|l|}{ Female } & 2.37 & \multicolumn{2}{|c|}{ Single-Person Households } & 2.32 \\
\hline \multicolumn{2}{|l|}{ Male } & 2.38 & \multicolumn{2}{|c|}{ Two-Person Households } & 2.40 \\
\hline \multicolumn{3}{|c|}{ Net Income Quartiles } & \multicolumn{3}{|c|}{ Savings Wealth Quartiles } \\
\hline 1 (low) & & 2.32 & 1(low) & & 2.07 \\
\hline 2 & & 2.38 & 2 & & 2.20 \\
\hline 3 & & 2.31 & 3 & & 2.44 \\
\hline 4(high) & & 2.46 & 4(high) & & 2.59 \\
\hline \multicolumn{3}{|c|}{ Basic Literacy Quartiles } & \multicolumn{3}{|c|}{ Advanced Literacy Quartiles } \\
\hline 1(low) & & 2.34 & $1($ low $)$ & & 2.19 \\
\hline 2 & & 2.30 & 2 & & 2.31 \\
\hline 3 & & 2.34 & 3 & & 2.45 \\
\hline 4(high) & & 2.43 & 4(high) & & 2.53 \\
\hline
\end{tabular}


Table 5

OLS of weighted APR on financial literacy.

The table reports OLS and IV estimates of the weighted APR of a household on financial literacy and several controls. Both IV-specifications use economics education and the financial situation of the oldest sibling as an instrument for advanced financial literacy. The reference group for the first consists of those with a lot of education in economics, while the base category for the second are those with no siblings and refusals. All IV estimates use two-stage least squares. Net financial wealth excludes savings wealth. The data are from the matched DNB Household Survey in 2005. Standard errors are adjusted for heteroskedasticity. ${ }^{*} \mathrm{p}<0.1 ; * * \mathrm{p}<0.05 ; * * * \mathrm{p}<0.01$

\begin{tabular}{|c|c|c|c|c|c|c|c|c|}
\hline & \multicolumn{2}{|c|}{ OLS (1) } & \multicolumn{2}{|c|}{ IV (1) } & \multicolumn{2}{|c|}{ OLS (2) } & \multicolumn{2}{|c|}{ IV (2) } \\
\hline & Estimate & SE & Estimate & SE & Estimate & SE & Estimate & SE \\
\hline Advanced financial literacy & $0.108 * * *$ & 0.030 & $0.285 * *$ & 0.132 & $0.105 * * *$ & 0.025 & $0.329 * * *$ & 0.116 \\
\hline \multicolumn{9}{|l|}{ Age dummies } \\
\hline $31-40$ years & $-0.286 * * *$ & 0.096 & $-0.195 *$ & 0.103 & $-0.242 * * *$ & 0.079 & $-0.167 *$ & 0.086 \\
\hline $41-50$ years & $-0.458 * * *$ & 0.098 & $-0.341 * * *$ & 0.109 & $-0.341 * * *$ & 0.082 & $-0.252 * * *$ & 0.090 \\
\hline $51-60$ years & $-0.457 * * *$ & 0.102 & $-0.377 * * *$ & 0.106 & $-0.306 * * *$ & 0.086 & $-0.265 * * *$ & 0.090 \\
\hline 61 years and older & $-0.534 * * *$ & 0.127 & $-0.491 * * *$ & 0.128 & $-0.489 * * *$ & 0.101 & $-0.466 * * *$ & 0.104 \\
\hline \multicolumn{9}{|l|}{ Education dummies } \\
\hline High school & -0.022 & 0.064 & -0.037 & 0.071 & 0.037 & 0.053 & 0.005 & 0.061 \\
\hline College & -0.040 & 0.066 & -0.053 & 0.075 & 0.035 & 0.056 & -0.009 & 0.067 \\
\hline Male & -0.035 & 0.056 & -0.068 & 0.073 & 0.008 & 0.047 & -0.045 & 0.064 \\
\hline Couple & 0.006 & 0.065 & 0.012 & 0.068 & 0.037 & 0.056 & 0.039 & 0.060 \\
\hline Number of children & -0.007 & 0.029 & -0.009 & 0.030 & -0.010 & 0.024 & -0.005 & 0.025 \\
\hline Basic financial literacy & -0.026 & 0.026 & -0.074 & 0.046 & -0.015 & 0.020 & $-0.074 *$ & 0.040 \\
\hline \multicolumn{9}{|l|}{ Occupation dummies } \\
\hline Employed & 0.047 & 0.078 & 0.035 & 0.081 & 0.000 & 0.063 & 0.004 & 0.067 \\
\hline Self-employed & 0.134 & 0.127 & 0.127 & 0.135 & 0.077 & 0.106 & 0.046 & 0.120 \\
\hline Unemployed & 0.254 & 0.158 & 0.227 & 0.164 & $0.210 *$ & 0.119 & $0.219 *$ & 0.128 \\
\hline Retired & 0.084 & 0.104 & 0.107 & 0.108 & 0.103 & 0.081 & 0.132 & 0.086 \\
\hline \multicolumn{9}{|l|}{ Net income quartiles } \\
\hline Second quartile & 0.034 & 0.080 & 0.005 & 0.084 & 0.048 & 0.061 & 0.034 & 0.067 \\
\hline Third quartile & -0.081 & 0.077 & $-0.141 *$ & 0.080 & -0.046 & 0.061 & -0.085 & 0.067 \\
\hline Fourth quartile & -0.002 & 0.078 & -0.061 & 0.081 & 0.015 & 0.064 & -0.029 & 0.068 \\
\hline \multicolumn{9}{|l|}{ Savings wealth quartiles } \\
\hline Second quartile & 0.123 & 0.100 & $0.194 *$ & 0.107 & 0.105 & 0.080 & $0.149 *$ & 0.089 \\
\hline Third quartile & $0.394 * * *$ & 0.100 & $0.440 * * *$ & 0.108 & $0.339 * * *$ & 0.079 & $0.373 * * *$ & 0.088 \\
\hline Fourth quartile & $0.559 * * *$ & 0.104 & $0.567 * * *$ & 0.113 & $0.508 * * *$ & 0.086 & $0.513 * * *$ & 0.095 \\
\hline \multicolumn{9}{|l|}{ Net financial wealth quartiles } \\
\hline Second quartile & $-0.136 *$ & 0.079 & $-0.151 *$ & 0.081 & -0.089 & 0.062 & -0.108 & 0.066 \\
\hline Third quartile & -0.032 & 0.083 & -0.063 & 0.091 & -0.029 & 0.068 & -0.065 & 0.077 \\
\hline Fourth quartile & -0.013 & 0.091 & -0.089 & 0.108 & -0.068 & 0.072 & $-0.155^{*}$ & 0.089 \\
\hline \multicolumn{9}{|l|}{ Net real wealth quartiles } \\
\hline Second quartile & -0.107 & 0.079 & -0.134 & 0.082 & -0.056 & 0.062 & -0.092 & 0.067 \\
\hline Third quartile & 0.024 & 0.085 & -0.016 & 0.087 & 0.006 & 0.070 & -0.049 & 0.075 \\
\hline Fourth quartile & -0.011 & 0.090 & -0.071 & 0.098 & -0.013 & 0.077 & -0.094 & 0.085 \\
\hline Constant & $2.292 * * *$ & 0.146 & $2.278 * * *$ & 0.164 & $2.439 * * *$ & 0.139 & $2.443 * * *$ & 0.159 \\
\hline Region dummies & yes & & yes & & yes & & yes & \\
\hline Account characteristics & & & & & yes & & yes & \\
\hline Bank fixed effects & & & & & yes & & yes & \\
\hline$N$ & 888 & & 828 & & 885 & & 826 & \\
\hline Adjusted R-squared & 0.12 & & 0.08 & & 0.41 & & 0.34 & \\
\hline Hansen J-test p-value & & & 0.51 & & & & 0.21 & \\
\hline F-statistic first stage & & & 10.42 & & & & 10.09 & \\
\hline Exogeneity test $\mathrm{p}$-value & & & 0.14 & & & & 0.04 & \\
\hline
\end{tabular}


Table 6

OLS of account-level APR on financial literacy.

The table reports OLS and IV estimates of the account-level APR of a savings account on financial literacy and several controls excluding accounts with volume below €50. Both IV-specifications use economics education and the financial situation of the oldest sibling as an instrument for advanced financial literacy. The reference group for the first consists of those with a lot of education in economics, while the base category for the second are those with no siblings and refusals. All IV estimates use two-stage least squares. The data are from the matched DNB Household Survey in 2005. Standard errors are clustered at the household level. * $\mathrm{p}<0.1 ; * * \mathrm{p}<0.05 ; * * * \mathrm{p}<0.01$

\begin{tabular}{|c|c|c|c|c|c|c|c|c|}
\hline & \multicolumn{2}{|c|}{ OLS (1) } & \multicolumn{2}{|c|}{ IV (1) } & \multicolumn{2}{|c|}{ OLS (2) } & \multicolumn{2}{|c|}{ IV (2) } \\
\hline & Estimate & SE & Estimate & SE & Estimate & SE & Estimate & SE \\
\hline Advanced financial literacy & $0.110 * * *$ & 0.031 & $0.275 * *$ & 0.136 & $0.108 * * *$ & 0.023 & $0.318^{* * *}$ & 0.112 \\
\hline \multicolumn{9}{|l|}{ Age dummies } \\
\hline $31-40$ years & $-0.249 * * *$ & 0.096 & $-0.184 *$ & 0.106 & $-0.203 * * *$ & 0.075 & $-0.161 *$ & 0.085 \\
\hline $41-50$ years & $-0.408 * * *$ & 0.095 & $-0.358 * * *$ & 0.101 & $-0.306 * * *$ & 0.071 & $-0.291 * * *$ & 0.077 \\
\hline $51-60$ years & $-0.341 * * *$ & 0.095 & $-0.363 * * *$ & 0.104 & $-0.231 * * *$ & 0.073 & $-0.304 * * *$ & 0.085 \\
\hline 61 years and older & $-0.507 * * *$ & 0.116 & $-0.542 * * *$ & 0.126 & $-0.462 * * *$ & 0.095 & $-0.538 * * *$ & 0.108 \\
\hline \multicolumn{9}{|l|}{ Education dummies } \\
\hline High school & 0.030 & 0.063 & 0.000 & 0.073 & $0.087 *$ & 0.050 & 0.048 & 0.061 \\
\hline College & -0.051 & 0.062 & -0.089 & 0.074 & 0.038 & 0.050 & -0.020 & 0.063 \\
\hline Male & -0.010 & 0.054 & -0.027 & 0.065 & 0.002 & 0.042 & -0.043 & 0.056 \\
\hline Couple & -0.032 & 0.059 & -0.034 & 0.062 & 0.048 & 0.052 & 0.018 & 0.056 \\
\hline Number of children & 0.018 & 0.028 & 0.014 & 0.030 & 0.004 & 0.022 & 0.003 & 0.023 \\
\hline Basic financial literacy & -0.029 & 0.026 & -0.071 & 0.052 & -0.024 & 0.018 & $-0.085^{* *}$ & 0.041 \\
\hline \multicolumn{9}{|l|}{ Occupation dummies } \\
\hline Employed & 0.066 & 0.100 & 0.055 & 0.111 & 0.063 & 0.085 & 0.024 & 0.107 \\
\hline Self-employed & 0.041 & 0.154 & 0.031 & 0.161 & 0.101 & 0.108 & 0.105 & 0.123 \\
\hline Unemployed & 0.101 & 0.077 & $0.140 *$ & 0.081 & $0.129 * *$ & 0.059 & $0.145 * *$ & 0.065 \\
\hline Retired & 0.081 & 0.100 & 0.108 & 0.101 & 0.113 & 0.083 & 0.129 & 0.087 \\
\hline \multicolumn{9}{|l|}{ Net income quartiles } \\
\hline Second quartile & -0.000 & 0.074 & -0.026 & 0.078 & 0.078 & 0.056 & 0.072 & 0.063 \\
\hline Third quartile & -0.093 & 0.070 & $-0.155 * *$ & 0.075 & -0.013 & 0.056 & -0.067 & 0.064 \\
\hline Fourth quartile & -0.080 & 0.072 & $-0.143^{*}$ & 0.080 & 0.008 & 0.058 & -0.046 & 0.066 \\
\hline \multicolumn{9}{|l|}{ Volume dummies } \\
\hline$€ 1,000-€ 2,500$ & 0.092 & 0.078 & 0.095 & 0.081 & $0.129 * *$ & 0.061 & $0.124 *$ & 0.066 \\
\hline$€ 2,500-€ 3,500$ & 0.147 & 0.092 & 0.140 & 0.095 & 0.037 & 0.071 & 0.033 & 0.072 \\
\hline$€ 3,500-€ 4,500$ & $0.255 * *$ & 0.103 & $0.252 * *$ & 0.104 & $0.215 * * *$ & 0.073 & $0.236 * * *$ & 0.079 \\
\hline$€ 4,500-€ 7,000$ & $0.440 * * *$ & 0.087 & $0.404 * * *$ & 0.089 & $0.312 * * *$ & 0.066 & $0.317 * * *$ & 0.070 \\
\hline$€ 7,000-€ 10,000$ & $0.446 * * *$ & 0.091 & $0.455 * * *$ & 0.095 & $0.319 * * *$ & 0.073 & $0.341 * * *$ & 0.079 \\
\hline$€ 10,000-€ 25,000$ & $0.478 * * *$ & 0.073 & $0.432 * * *$ & 0.078 & $0.414 * * *$ & 0.057 & $0.395 * * *$ & 0.062 \\
\hline$€ 25,000-€ 45,000$ & $0.605 * * *$ & 0.083 & $0.578 * * *$ & 0.088 & $0.532 * * *$ & 0.071 & $0.519 * * *$ & 0.076 \\
\hline$€ 45,000$ or more & $0.776 * * *$ & 0.086 & $0.764 * * *$ & 0.089 & $0.596 * * *$ & 0.072 & $0.614 * * *$ & 0.075 \\
\hline \multicolumn{9}{|l|}{ Account characteristics } \\
\hline Minimum amount & & & & & 0.036 & 0.084 & 0.009 & 0.089 \\
\hline Lowest balance bonus & & & & & $0.216^{* *}$ & 0.096 & $0.202 * *$ & 0.102 \\
\hline Balance growth bonus & & & & & $1.732 * * *$ & 0.103 & $1.773 * * *$ & 0.114 \\
\hline Limited withdrawal & & & & & $1.428 * * *$ & 0.072 & $1.386 * * *$ & 0.092 \\
\hline Additional fees & & & & & $-0.246 * * *$ & 0.059 & $-0.300 * * *$ & 0.065 \\
\hline Salary account & & & & & $0.968 * * *$ & 0.123 & $0.936 * * *$ & 0.121 \\
\hline Joint ownership & & & & & -0.031 & 0.048 & -0.005 & 0.050 \\
\hline Third party ownership & & & & & -0.022 & 0.060 & 0.032 & 0.071 \\
\hline Constant & $2.295 * * *$ & 0.129 & $2.314 * * *$ & 0.149 & $2.332 * * *$ & 0.112 & $2.383 * * *$ & 0.136 \\
\hline Region dummies & yes & & yes & & yes & & yes & \\
\hline Bank fixed effects & & & & & yes & & yes & \\
\hline$N$ & 1,575 & & 1,471 & & 1,572 & & 1,468 & \\
\hline Adjusted R-squared & 0.09 & & 0.07 & & 0.46 & & 0.42 & \\
\hline Hansen J-test p-value & & & 0.78 & & & & 0.68 & \\
\hline F-statistic first stage & & & 9.22 & & & & 9.93 & \\
\hline Exogeneity test p-value & & & 0.24 & & & & 0.06 & \\
\hline
\end{tabular}


Table 7

OLS of APR on financial literacy and online banking.

The table reports OLS and IV estimates of the weighted (Panel A) and account-level APR (Panel B) of savings accounts on financial literacy and several controls. In Panel B, accounts with volume below $€ 50$ are excluded. For demographics and other controls compare to Table 5 (Panel A) and Table 6 (Panel B). IV uses economics education and the financial situation of the oldest sibling as an instrument for advanced financial literacy. The reference group for the first consists of those with a lot of education in economics, while the base category for the second are those with no siblings and refusals. All IV estimates use two-stage least squares. The data are from the matched DNB Household Survey in 2005. Standard errors are adjusted for heteroskedasticity allowing for clustering at the household level. * $\mathrm{p}<0.1 ; * * \mathrm{p}<0.05 ; * * * \mathrm{p}<0.01$

Panel A: Household level

\begin{tabular}{lcccc}
\hline & \multicolumn{2}{c}{ OLS } & Estimate & SE \\
\hline Advanced financial literacy & Estimate & SE & $0.224^{* *}$ & 0.091 \\
Internet account & $0.074^{* * *}$ & 0.02 & $0.906^{* * *}$ & 0.043 \\
Demographics and other controls & $0.919^{* * *}$ & 0.04 & yes & \\
Region dummies & yes & & yes & \\
Account characteristics & yes & & yes \\
Bank fixed effects & yes & & yes \\
$\mathrm{N}$ & yes & & 826 \\
Adjusted R-squared & 885 & & 0.64 \\
Hansen J-test p-value & 0.67 & & 0.46 & \\
F-statistic first stage & & & 10.03 & \\
Exogeneity test p-value & & & 0.07 & \\
\hline
\end{tabular}

Panel B: Account level

\begin{tabular}{lcccc}
\hline & \multicolumn{2}{c}{ OLS } & \multicolumn{2}{c}{ IV } \\
& Estimate & SE & Estimate & SE \\
\hline Advanced financial literacy & $0.060^{* * *}$ & 0.013 & $0.238^{* * *}$ & 0.069 \\
Internet account & $1.297^{* * *}$ & 0.032 & $1.275^{* * *}$ & 0.035 \\
Demographics and other controls & yes & & yes & \\
Region dummies & yes & & yes & \\
Account characteristics & yes & & yes \\
Bank fixed effects & yes & & yes \\
$\mathrm{N}$ & 1,572 & & 1,468 \\
Adjusted R-squared & 0.81 & & 0.78 \\
Hansen J-test p-value & & & 0.92 & \\
F-statistic first stage & & & 9.93 & \\
Exogeneity test p-value & & & 0.00 & \\
\hline
\end{tabular}


Table 8

Alternative definitions or functional forms for wealth, literacy, and APR.

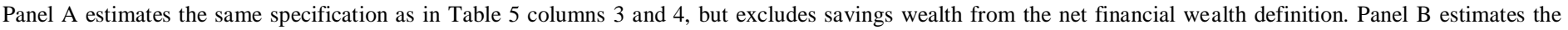

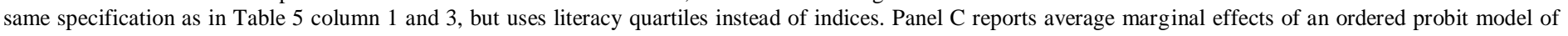

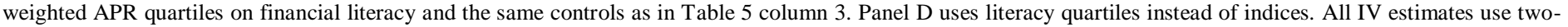

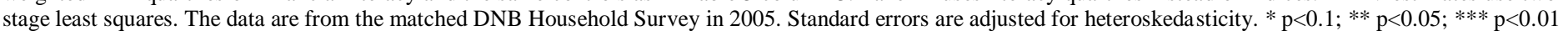

Panel A: OLS of weighted APR on financial literacy excluding savings wealth

\begin{tabular}{|c|c|c|c|c|}
\hline & \multicolumn{2}{|c|}{ OLS } & \multicolumn{2}{|c|}{ IV } \\
\hline & Estimate & SE & Estimate & SE \\
\hline Advanced financial literacy & $0.105 * * *$ & 0.026 & $0.318 * * *$ & 0.115 \\
\hline Demographics and other controls & yes & & yes & \\
\hline Region dummies & yes & & yes & \\
\hline Account characteristics & yes & & yes & \\
\hline Bank fixed effects & yes & & yes & \\
\hline$N$ & 885 & & 826 & \\
\hline Adjusted R-squared & 0.37 & & 0.31 & \\
\hline Hansen J-test p-value & & & 0.15 & \\
\hline F-statistic first stage & & & 10.02 & \\
\hline Exogeneity test $\mathrm{p}$-value & & & 0.05 & \\
\hline \multicolumn{5}{|c|}{ Panel B: OLS of weighted APR on financial literacy quartiles } \\
\hline & \multicolumn{2}{|c|}{ OLS $(1)$} & \multicolumn{2}{|c|}{ OLS $(2)$} \\
\hline & Estimate & SE & Estimate & SE \\
\hline \multicolumn{5}{|l|}{ Advanced financial literacy quartiles } \\
\hline Second quartile & $0.137^{*}$ & 0.076 & $0.165 * * *$ & 0.076 \\
\hline Third quartile & $0.234 * * *$ & 0.074 & $0.193 * * *$ & 0.079 \\
\hline Fourth quartile & $0.305 * * *$ & 0.074 & $0.290 * * *$ & 0.086 \\
\hline Demographics and other controls & yes & & yes & \\
\hline Region dummies & yes & & yes & \\
\hline Account characteristics & & & yes & \\
\hline Bank fixed effects & & & yes & \\
\hline$N$ & 888 & & 885 & \\
\hline Adjusted R-squared & 0.12 & & 0.41 & \\
\hline
\end{tabular}

Panel C: Ordered probit of weighted APR quartiles on financial literacy indices

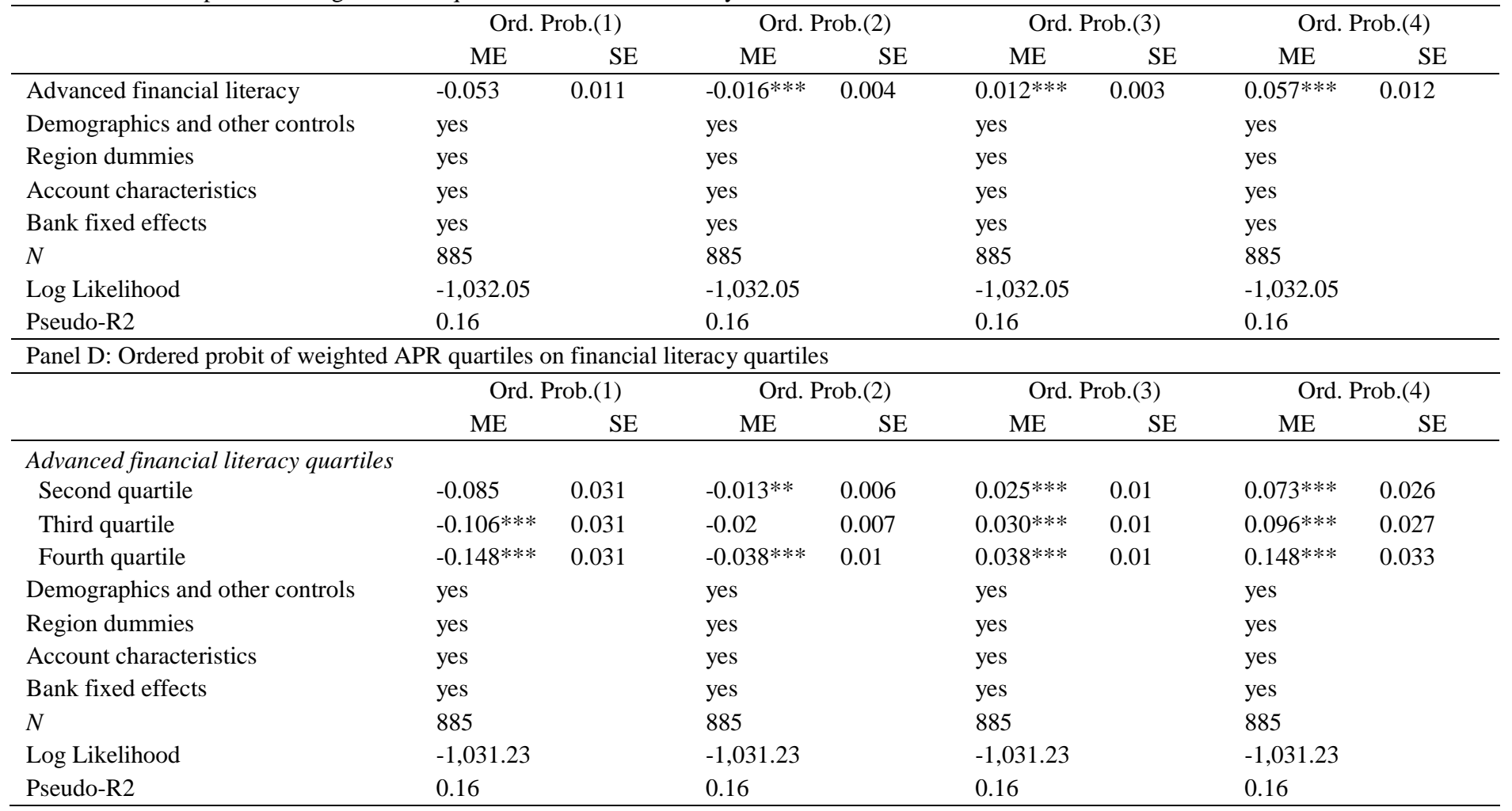




\section{Appendix A. Descriptive Statistics on Savings Accounts}

\section{Table A1}

Summary statistics account-level variables.

The sample consists of those households later used in the regression analysis. The data are from the matched DNB Household Survey 2005.

\begin{tabular}{|c|c|c|c|c|c|c|}
\hline Variable & Mean & Std. Dev. & 25th pct. & Median & 75th pet. & $\mathrm{N}$ \\
\hline APR & 2.37 & 0.87 & 1.55 & 2.50 & 3.10 & 1575 \\
\hline Savings account volume & 10,973 & 24,651 & 875 & 3,500 & 12,000 & 1575 \\
\hline Individual ownership & 0.47 & 0.50 & 0.00 & 0.00 & 1.00 & 1572 \\
\hline Joint ownership & 0.41 & 0.49 & 0.00 & 0.00 & 1.00 & 1572 \\
\hline Third party ownership & 0.12 & 0.33 & 0.00 & 0.00 & 0.00 & 1572 \\
\hline Restricted & 0.49 & 0.50 & 0.00 & 0.00 & 1.00 & 1575 \\
\hline Internet account & 0.38 & 0.49 & 0.00 & 0.00 & 1.00 & 1575 \\
\hline Minimum amount & 0.15 & 0.36 & 0.00 & 0.00 & 0.00 & 1575 \\
\hline Minimum time bonus & 0.27 & 0.44 & 0.00 & 0.00 & 1.00 & 1575 \\
\hline Balance growth bonus & 0.02 & 0.15 & 0.00 & 0.00 & 0.00 & 1575 \\
\hline Limited withdrawal & 0.01 & 0.09 & 0.00 & 0.00 & 0.00 & 1575 \\
\hline Additional fees & 0.08 & 0.27 & 0.00 & 0.00 & 0.00 & 1575 \\
\hline Salary account & 0.02 & 0.15 & 0.00 & 0.00 & 0.00 & 1575 \\
\hline
\end{tabular}




\section{Appendix B. First Stage Regressions}

Table B1

First stage regression weighted APR.

The table reports first stage estimates from the IV-regressions in Table 5 including the two instruments economics education and the financial situation of the oldest sibling. The reference group for the first consists of those with a lot of education in economics, while the base category for the second are those with no siblings and refusals. The data are from the matched DNB Household Survey 2005. Standard errors are adjusted for heteroskedasticity. ${ }^{*} \mathrm{p}<0.1 ; * * \mathrm{p}<0.05 ; * * * \mathrm{p}<0.01$

\begin{tabular}{|c|c|c|c|c|}
\hline \multirow{3}{*}{ Financial situation oldest sibling } & \multicolumn{2}{|c|}{ OLS (1) } & \multicolumn{2}{|c|}{ OLS (2) } \\
\hline & \multirow[t]{2}{*}{ Estimate } & \multirow[t]{2}{*}{ SE } & \multirow[t]{2}{*}{ Estimate } & \multirow[t]{2}{*}{ SE } \\
\hline & & & & \\
\hline & $0.274 * * *$ & 0.095 & $0.274 * * *$ & 0.093 \\
\hline The same or better & $0.176^{*}$ & 0.092 & $0.176^{* *}$ & 0.090 \\
\hline \multicolumn{5}{|l|}{ Economics education } \\
\hline Some & $-0.227 * * *$ & 0.069 & $-0.216^{* * * *}$ & 0.070 \\
\hline Little & $-0.311^{* * *}$ & 0.079 & $-0.307 * * *$ & 0.079 \\
\hline Hardly at all & $-0.579 * * *$ & 0.092 & $-0.565 * * *$ & 0.093 \\
\hline \multicolumn{5}{|l|}{ Age dummies } \\
\hline $31-40$ years & -0.159 & 0.116 & -0.145 & 0.118 \\
\hline $41-50$ years & -0.171 & 0.112 & -0.153 & 0.114 \\
\hline $51-60$ years & 0.041 & 0.107 & 0.056 & 0.110 \\
\hline 61 years and older & 0.141 & 0.142 & 0.154 & 0.146 \\
\hline \multicolumn{5}{|l|}{ Education dummies } \\
\hline High school & $0.177 * *$ & 0.079 & $0.171 * *$ & 0.080 \\
\hline College & $0.195 * * *$ & 0.075 & $0.185 * *$ & 0.077 \\
\hline Male & $0.271 * * *$ & 0.066 & $0.277 * * *$ & 0.066 \\
\hline Couple & -0.055 & 0.072 & -0.044 & 0.073 \\
\hline Number of Children & -0.027 & 0.033 & -0.027 & 0.034 \\
\hline Basic financial literacy & $0.261 * * *$ & 0.035 & $0.268 * * *$ & 0.034 \\
\hline \multicolumn{5}{|l|}{ Occupation dummies } \\
\hline Employed & 0.034 & 0.095 & 0.050 & 0.095 \\
\hline Self-employed & $0.283 * *$ & 0.142 & $0.285^{* *}$ & 0.144 \\
\hline Unemployed & 0.121 & 0.164 & 0.126 & 0.172 \\
\hline Retired & -0.065 & 0.123 & -0.048 & 0.128 \\
\hline \multicolumn{5}{|l|}{ Net income quartiles } \\
\hline Second quartile & 0.121 & 0.100 & 0.109 & 0.100 \\
\hline Third quartile & 0.088 & 0.098 & 0.065 & 0.099 \\
\hline Fourth quartile & 0.107 & 0.102 & 0.091 & 0.101 \\
\hline \multicolumn{5}{|l|}{ Savings wealth quartiles } \\
\hline Second quartile & 0.041 & 0.120 & 0.038 & 0.120 \\
\hline Third quartile & 0.034 & 0.122 & 0.009 & 0.123 \\
\hline Fourth quartile & 0.104 & 0.124 & 0.063 & 0.128 \\
\hline \multicolumn{5}{|c|}{ Net financial wealth quartiles } \\
\hline Second quartile & 0.021 & 0.099 & 0.044 & 0.099 \\
\hline Third quartile & $0.193 * *$ & 0.098 & $0.207 * *$ & 0.097 \\
\hline Fourth quartile & $0.368 * * *$ & 0.098 & $0.378 * * *$ & 0.097 \\
\hline \multicolumn{5}{|l|}{ Net real wealth quartiles } \\
\hline Second quartile & 0.058 & 0.095 & 0.046 & 0.094 \\
\hline Third quartile & 0.050 & 0.100 & 0.055 & 0.100 \\
\hline Fourth quartile & $0.197^{*}$ & 0.103 & $0.202 *$ & 0.103 \\
\hline Constant & $-0.395 * *$ & 0.188 & -0.256 & 0.210 \\
\hline Region dummies & yes & & yes & \\
\hline Account characteristics & & & yes & \\
\hline Bank fixed effects & & & yes & \\
\hline$N$ & 828 & & 826 & \\
\hline Adjusted R-squared & 0.32 & & 0.32 & \\
\hline F-statistic first stage & 10.42 & & 10.09 & \\
\hline
\end{tabular}


Table B2

First stage regression account-level APR.

The table reports first stage estimates from the IV-regressions in Table 6 including the two instruments economics education and the financial situation of the oldest sibling. The reference group for the first consists of those with a lot of education in economics, while the base category for the second are those with no siblings and refusals. The data are from the matched DNB Household Survey 2005. Standard errors are clustered at the household level. * $\mathrm{p}<0.1 ; * * \mathrm{p}<0.05$; *** $\mathrm{p}<0.01$

\begin{tabular}{|c|c|c|c|c|}
\hline & \multicolumn{2}{|c|}{ OLS (1) } & \multicolumn{2}{|c|}{ OLS (2) } \\
\hline & Estimate & SE & Estimate & SE \\
\hline \multicolumn{5}{|c|}{ Financial situation oldest sibling } \\
\hline Worse & $0.260 * * *$ & 0.097 & $0.240 * * *$ & 0.093 \\
\hline The same or better & 0.143 & 0.090 & 0.139 & 0.087 \\
\hline \multicolumn{5}{|l|}{ Economics education } \\
\hline Some & $-0.271 * * *$ & 0.074 & $-0.256^{* * *}$ & 0.071 \\
\hline Little & $-0.357 * * *$ & 0.080 & $-0.359 * * *$ & 0.080 \\
\hline Hardly at all & $-0.577 * * *$ & 0.092 & $-0.574 * * *$ & 0.090 \\
\hline \multicolumn{5}{|l|}{ Age dummies } \\
\hline $31-40$ years & -0.140 & 0.141 & -0.122 & 0.138 \\
\hline $41-50$ years & -0.052 & 0.128 & -0.016 & 0.123 \\
\hline $51-60$ years & $0.329 * * *$ & 0.114 & $0.336 * * *$ & 0.111 \\
\hline 61 years and older & $0.383 * * *$ & 0.147 & $0.410 * * *$ & 0.145 \\
\hline \multicolumn{5}{|l|}{ Education dummies } \\
\hline High school & $0.190 * *$ & 0.081 & $0.180 * *$ & 0.079 \\
\hline College & $0.212 * * *$ & 0.079 & $0.206^{* * *}$ & 0.078 \\
\hline Male & $0.198 * * *$ & 0.068 & $0.228 * * *$ & 0.066 \\
\hline Couple & -0.001 & 0.073 & 0.080 & 0.080 \\
\hline Number of Children & -0.033 & 0.038 & -0.028 & 0.038 \\
\hline Basic financial literacy & $0.305 * * *$ & 0.039 & $0.298 * * *$ & 0.037 \\
\hline \multicolumn{5}{|l|}{ Occupation dummies } \\
\hline Employed & 0.211 & 0.191 & 0.187 & 0.192 \\
\hline Self-employed & -0.017 & 0.157 & 0.007 & 0.145 \\
\hline Unemployed & -0.106 & 0.106 & -0.103 & 0.103 \\
\hline Retired & -0.101 & 0.124 & -0.103 & 0.124 \\
\hline \multicolumn{5}{|l|}{ Net income quartiles } \\
\hline Second quartile & 0.067 & 0.107 & 0.090 & 0.104 \\
\hline Third quartile & $0.196 *$ & 0.103 & $0.193^{*}$ & 0.101 \\
\hline Fourth quartile & 0.145 & 0.110 & 0.151 & 0.108 \\
\hline \multicolumn{5}{|l|}{ Volume dummies } \\
\hline$€ 1,000-€ 2,500$ & 0.058 & 0.077 & 0.072 & 0.068 \\
\hline$€ 2,500-€ 3,500$ & $0.162 * *$ & 0.080 & 0.107 & 0.079 \\
\hline$€ 3,500-€ 4,500$ & 0.038 & 0.109 & 0.005 & 0.110 \\
\hline$€ 4,500-€ 7,000$ & 0.070 & 0.091 & 0.022 & 0.089 \\
\hline$€ 7,000-€ 10,000$ & 0.025 & 0.097 & -0.026 & 0.097 \\
\hline$€ 10,000-€ 25,000$ & 0.102 & 0.074 & 0.071 & 0.073 \\
\hline$€ 25,000-€ 45,000$ & 0.050 & 0.096 & -0.001 & 0.103 \\
\hline$€ 45,000$ or more & 0.055 & 0.121 & 0.033 & 0.113 \\
\hline \multicolumn{5}{|l|}{ Account characteristics } \\
\hline Minimum amount & & & 0.079 & 0.074 \\
\hline Lowest balance bonus & & & 0.010 & 0.072 \\
\hline Balance growth bonus & & & -0.105 & 0.178 \\
\hline Limited withdrawal & & & 0.195 & 0.198 \\
\hline Additional fees & & & $0.151^{*}$ & 0.084 \\
\hline Salary account & & & -0.084 & 0.149 \\
\hline holder $2==2$ & & & -0.046 & 0.060 \\
\hline holder $2==3$ & & & $-0.271 * * *$ & 0.089 \\
\hline Constant & -0.233 & 0.181 & -0.183 & 0.199 \\
\hline Region dummies & yes & & yes & \\
\hline Bank fixed effects & & & yes & \\
\hline$N$ & 1,500 & & 1,473 & \\
\hline Adjusted R-squared & 0.32 & & 0.33 & \\
\hline F-statistic first stage & 9.74 & & 10.19 & \\
\hline
\end{tabular}




\section{Appendix C. Details on Data Processing}

In what follows, we first discuss how we process the raw information from the DHS data and subsequently how we match the DHS to the market data on interest rates.

\subsection{DNB Household Survey (DHS)}

Whereas the majority of survey respondents provide a bank name, the data on the names of savings accounts contain some typos, abbreviations, and few inconsistencies. We process this raw information in the DHS in the following way. Using the bank and account names from the market interest rate data as a reference for the correct spelling, we replace all incorrectly spelled names and abbreviations in the DHS by their proper name. We replace those cases in which participants report outdated names of accounts by the names of their successor accounts. Finally, we set all potential inconsistent cases to missing. ${ }^{39}$

As we later match the DHS and market data based on volume as well, we also recover missing volumes of individual savings accounts following the procedure used by the official provider of the DHS (CentERdata). CentERdata first recovers volumes for individual savings accounts (details follow) and then aggregates over all accounts of each household member yielding total savings volume per household member (i.e., at the individual level). Only the recovered volume of the latter is available in the public version of the dataset. However, we are able to recover the large majority of the inserted values for individual savings accounts by following the same process that CentERdata has applied to calculate total savings account volume per household member. ${ }^{40}$

First, if a respondent does not report the exact amount of a savings account, the respondent is asked to choose from a sequence of follow-up questions in the form of unfolding brackets. In this case, we use the mid-point of the bracketed answer or the lower bound in case of the highest open-ended category ( $€ 25,000$ or more). This leaves $10.3 \%$ of accounts with missing volume. Second, for these missing cases, we use the average amount of this savings account over the last two years. This leaves $8.1 \%$ of accounts with missing volume. For the remaining individual

\footnotetext{
${ }^{39}$ For example, some respondents report accounts not offered by the reported bank in 2005 .

40 Details can be found in the documentation of the DHS 2005 wave (available at: http://cdata3.uvt.nl/dhs/files/CodebookWave2005English.pdf)
} 
household members with at least one account with unreported volume, an imputed value for total savings volume was used by CentERdata. This was derived from a regression of total savings volume on a large set of individual characteristics. We use this imputed value to recover the volume of individual savings accounts in the following way. If only one account of a household member is left with missing volume, we use the difference between the total savings volume and the sum of all reported account volumes of that individual to fill in the single missing volume. ${ }^{41}$ This still leaves few individual household members with more than one account with missing volume. For those household members, we distribute this difference equally across all savings accounts with remaining missing volume. ${ }^{42}$

\subsection{Matching Procedure}

The DHS panel asks to report all asset information as of December $31^{\text {st }}$ of the year preceding the survey interviews. We thus match the interest rate of the last week of December to the DHS in 2005 based on bank name, account name, and invested volume.

In total, we successfully merge $79 \%$ of all individual saving accounts (corresponding to $84 \%$ of total household savings volume on average). We impute the remaining missing interest rates as follows. For each bank, we first determine the most prevalent account among households in the DHS. Given the bank at which an account is held, we then assign the APR of the most prevalent account in that particular bank, taking into account the invested volume on each account. Last, $2.5 \%$ of all savings accounts with reported names in the DHS in 2005 are deposit accounts, which are not available in the market data on interest rates. As compared to savings accounts, deposit accounts combine fixed duration with high minimum balance requirements, and in return typically offer higher rates. Thus, we assign to each deposit account the highest interest rate of all accounts within the bank, at which the particular account is held, as well as the restrictions for minimum balance requirements and lowest balance bonus. Table $\mathrm{C} 1$ shows the

\footnotetext{
${ }^{41} 60 \%$ of those household members hold only one account and thus total volume and individual account volume are equivalent.

${ }^{42}$ Note that in the last two cases, we only consider accounts that do not exceed the total number of accounts as originally stated by the respondent, for example, we only consider the first three reported accounts of a household that claims to have 3 accounts in total but reports four. The same approach is used in the DHS for the calculation of total savings wealth.
} 
share of accounts with missing interest rate information by bank category before and after our imputation.

\section{Table C1}

Share of Accounts with missing interest rate.

This table contains the share of accounts with missing interest rate information by bank category before and after imputation. ING and its subsidiary Postbank are grouped together to the single entity 'ING Bank'. The data are from the matched DNB Household Survey 2005.

\begin{tabular}{lrrr}
\hline Bank Name & Before Imputation & After Imputation & $\mathrm{N}$ \\
\hline ABN AMRO & $23.0 \%$ & $0.0 \%$ & 309 \\
ING Bank & $13.3 \%$ & $0.0 \%$ & 847 \\
Rabobank & $17.0 \%$ & $0.0 \%$ & 717 \\
Fortis Bank & $41.7 \%$ & $0.0 \%$ & 108 \\
SNS Bank & $38.8 \%$ & $0.0 \%$ & 98 \\
Other Banks & $31.7 \%$ & $5.2 \%$ & 388 \\
Total & $20.8 \%$ & $0.8 \%$ & 2,467 \\
\hline
\end{tabular}

As can be seen from the table, the merging process is quite successful for the three largest banks with a remaining fraction of accounts with missing APR between 13\% and 23\%. As regards accounts at medium and small banks, interest rate information is missing in approximately $31 \%$ and $40 \%$ of accounts held in these banks (note, however, that these banks together have only $24 \%$ market share in terms of number of accounts). After our imputation, there is only a very small fraction of accounts left with missing APR (5.2\% of accounts held at small banks that correspond to $0.8 \%$ of all accounts). ${ }^{43}$

In any case, as we discuss in the robustness section, our baseline results are virtually unaffected when we do not apply the aforementioned imputation process and use only accounts with originally matched interest rates.

\footnotetext{
${ }^{43}$ Missing interest rate information (after imputation) in the category 'Small Banks' is due to some very small banks, for which no account names were reported. In this case, the most frequently named account cannot be determined, making imputation impossible. Instead, we assign to these very few cases the average interest rate as of December 2004.
} 


\title{
Appendix D. Details on key questions used (Not for publication, for referee use only)
}

\author{
Account Holder \\ SPA71 thru SPA77 \\ Who is the account holder of your [1st thru 7 th] account? \\ 1 the account is registered in my own name ………..................................................... SPA91 \\ 2 the account is registered in my partner's/spouse's name ............................................. SPA91 \\ 3 the account is registered jointly in my own name and someone else's name \\ (e.g. partner/spouse) (.................................................................................... SPA91 \\ 4 the account is registered in (one of) my parents' name ............................................... SPA91

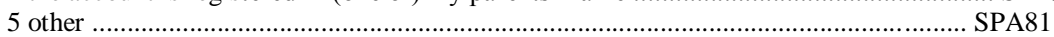

Note:

We group category 2,4 and 5 into one category 'third party ownership' due to a small number of observations in these categories.

\section{Account Characteristics}

(1) Minimum amount: Minimum amount required to earn full interest rate

(2) Lowest balance bonus: Balance may not fall below specified amount threshold during calendar year/quarter to earn full rate

(3) Balance growth bonus: Balance needs to grow by specified amount per calendar year/quarter

(4) Limited withdrawal: Maximum withdrawal per month

(5) Additional fees: withdrawal / account fees

(6) Salary account: Salary account required at the same bank

(7) Internet account: Account is fully managed online

\section{Bank Fixed Effects}

SPA91 thru SPA97

With which bank or financial institution is your [1st thru 7th] account registered?

1 ABN AMRO …….................................................................................. SPA 121

2 Postbank ………………………………………………………………….... SPA 121

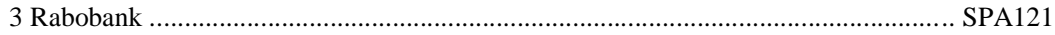

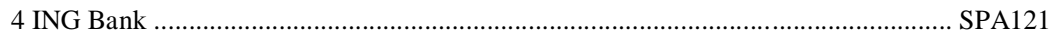

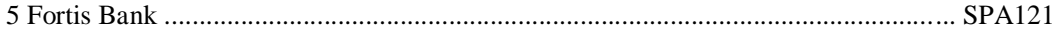

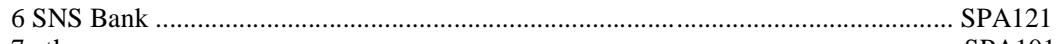

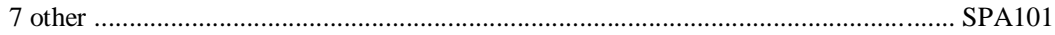

Note:

We group ING and Postbank together as the former mainly operates through the latter in the market for savings accounts.

\section{Economics Education}

How much of your education was devoted to economics?

1 A lot

2 Some

3 Little

4 Hardly at all

5 Do not know

6 Refusal

Note:

We group the last three categories together and use dummies for each category in the regressions analysis, in which 'a lot of education in economics' serves as the base category.

\section{Financial Literacy (Advanced)}

(1) Which statement describes the main function of the stock market? (i) The stock market helps to predict stock earnings; (ii) the stock market results in an increase in the price of stocks; (iii) the stock market brings people who want to buy stocks together with those who want to sell stocks; (iv) none of the above; (v) do not know; (vi) refusal.

(2) What happens if somebody buys the stock of firm B in the stock market? (i) He owns a part of firm B; (ii) he has lent money to firm B; (iii) he is liable for firm B debt; (iv) none of the above; (v) do not know; (vi) refusal.

(3) Which statement about mutual funds is correct? (i) Once one invests in a mutual fund, one cannot withdraw the money in the first year; (ii) mutual funds can invest in several assets, for example, invest in both stocks and bonds; (iii) mutual funds pay a guaranteed rate of return which depends on their past performance; (iv) none of the above; (v) do not know; (vi) refusal.

(4) What happens if somebody buys a bond of firm B? (i) He owns a part of firm B; (ii) he has lent money to firm B; (iii) he is liable for firm B_s debts; (iv) none of the above; (v) do not know; (vi) refusal. 
(5) Considering a long time period (e.g. 10 or 20 years), which asset normally gives the highest return? (i) Savings accounts; (ii) bonds; (iii) stocks; (iv) do not know; (v) refusal.

(6) When an investor spreads his money among different assets, does the risk of losing money (i) increase; (ii) decrease; (iii) stay the same; (iv) do not know; (v) refusal.

(7) If you buy a 10-year bond, it means you cannot sell it after five years without incurring a major penalty. (i) True; (ii) false; (iii) do not know; (iv) refusal.

(8) Stocks are normally riskier than bonds. (i) True; (ii) false; (iii) do not know; (iv) refusal.

(9) Buying a company fund usually provides a safer return than a stock mutual fund. (i) True; (ii) false; (iii) do not know; (iv) refusal.

(10) If the interest rate falls, what should happen to bond prices? (i) Rise; (ii) fall; (iii) stay the same; (iv) none of the above; (v) do not know; (vi) refusal.

(11) Normally, which asset displays the highest fluctuations over time? (i) Savings accounts; (ii) bonds; (iii) stocks; (iv) do not know; (v) refusal.

Note:

The index for advanced financial literacy is gratefully borrowed from van Rooij et al. (2011) and is the result of a factor analysis on the above set of questions as described in the appendix of their paper.

\section{Financial Literacy (Basic)}

(1) Suppose you had $€ 100$ in a savings account and the interest rate was $2 \%$ per year. After five years, how much do you think you would have in the account if you left the money to grow? (i) More than $€ 102$; (ii) exactly $€ 102$; (iii) less than €102; (iv) do not know; (v) refusal.

(2) Suppose you had $€ 100$ in a savings account and the interest rate is $20 \%$ per year and you never withdraw money or interest payments. After five years, how much would you have on this account in total? (i) More than €200; (ii) exactly €200; (iii) less than €200; (iv) do not know; (v) refusal.

(3) Imagine that the interest rate on your savings account was $1 \%$ per year and inflation was $2 \%$ per year. After one year, how much would you be able to buy with the money in this account? (i) More than today; (ii) exactly the same; (iii) less than today; (iv) do not know; (v) refusal.

(4) Assume a friend inherits $€ 10,000$ today and his sibling inherits $€ 10,000$ three years from now. Who is richer because of the inheritance? (i) My friend; (ii) his sibling; (iii) they are equally rich; (iv) do not know; (v) refusal.

(5) Suppose that in the year 2010, your income has doubled and prices of all goods have doubled too. In 2010 , how much will you be able to buy with your income? (i) More than today; (ii) the same; (iii) less than today; (iv) do not know; (v) refusal.

Note:

The index for basic financial literacy is gratefully borrowed from van Rooij et al. (2011) and is the result of a factor analysis on the above set of questions as described in the appendix of their paper.

\section{Financial Situation of the Oldest Sibling}

Would you say that your oldest [brother/sister] is in worse, better, or about the same financial condition than you?

1 Worse

2 Better

3 About the same

4 Refusal

5 Do not know

Note:

We group the last two categories and those with no siblings together and use dummies for each category in the regressions analysis in which Don't know/Refusal/No Sibling serves as the base category.

\section{Hours Worked}

UURWERK

How many hours per week do/did you on average IN FACT spend on your (last) (most important) job? For this question it doesn't make any difference whether overtime work is/was paid for or not.

number of hours:

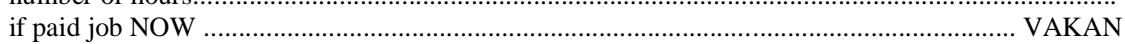

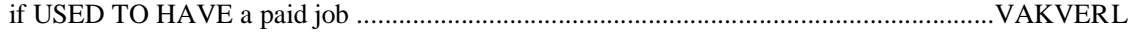

\section{Last Year's Net Income}

\section{INKNORM}

Is this income unusually high or low compared to the income you would expect in a 'regular' year, or is 
it regular?

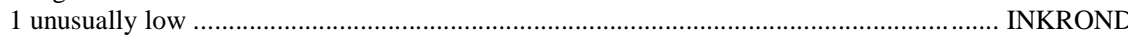

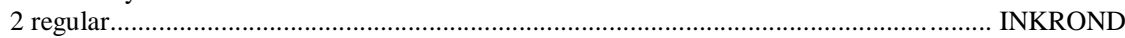

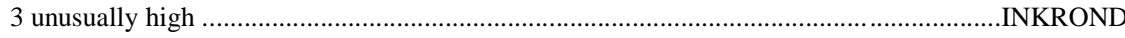

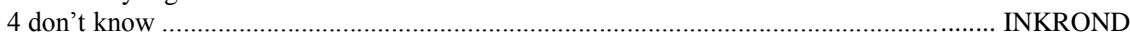

Note:

We set 'don't know' to missing and group the categories 2 and 3 together. The resulting category serves as the base in the regression analysis.

\section{Savings Wealth}

SPA3 What was the total balance of your SAVINGS OR DEPOSIT ACCOUNTS on 31 December 2004?

amount:.. SPA71

don't know

SPA4

\section{Net Financial Wealth}

Sum of checking, deposit books, savings certificates, bonds, stocks, funds, options, employer-sponsored savings plan, insurances, and other financial wealth minus total financial debt.

Note:

We count financial wealth as missing only if all asset subcomponents are missing.

\section{Net Income}

Equal to the derived net income on individual level as provided by CentER in the aggregated data on income and aggregate to household level.

Note:

In contrast to the DHS which counts net income as missing if one of the sub components is missing, we count net income as missing only if all asset subcomponents are missing. Bot variables are highly similar in terms of distributional aspects, since often only small subcomponents are not reported.

\section{Net Real Wealth}

Difference between real assets and real debt. Real assets are the sum of home equity (value of first and second house as well as pieces of real estate), business wealth, and other real wealth (cars, motorbikes, boats and caravans). Real debt is the sum of mortgages on the first and second house as well on other pieces of real estate.

\section{Risk Aversion}

R1) Suppose that you are the only income earner in the family, and you have a good job guaranteed to give you your current (family) income every year for life. You are given the opportunity to take a new, equally good job, with a 50\% chance it will double your (family) income and a $50 \%$ chance that it will cut your (family) income by a third. Would you take the new job?

[] Yes [ ] No [] Do not know

[If R1=="yes", then R2]

R2) Suppose the chances were 50\% that it would double your (family) income, and $50 \%$ that it would cut it in half. Would you take the new job? [ ] Yes [ ] No [] Do not know

[If R1=="no" or "do not know", then R3]

R3) Suppose the chances were $50 \%$ that it would double your (family) income and $50 \%$ that it would cut it by $20 \%$. Would you then take the new job?

[] Yes [ ] No [] Do not know

Note:

We follow the grouping as performed by van Rooij, Lusardi and Alessie (2011). Least risk averse: choosing the most risky option twice; medium risk averse: choosing the most risky option in the first but not in the second question; risk averse: safe option in the first but not in the second question; most risk averse: choosing the safe option twice; do not know: no choice in the first question. 


\section{IMFS WORKING PAPER SERIES}

\section{Recent Issues}

87 / 2015

$86 / 2015$

84 / 2014

$83 / 2014$

$82 / 2014$

81 / 2014

$80 / 2014$

$79 / 2014$

$78 / 2014$

77 / 2014

$76 / 2013$

75 / $2013 \quad$ Athanasios Orphanides

$74 / 2013$

$73 / 2013$
Y. Emily Yoo

Falko Fecht

Roman Inderst

Sebastian Pfeil

Markus Behn

Rainer Haselmann

Thomas Kick

Vikrant Vig

Elena Afanasyeva

Jochen Güntner

Athanasios Orphanides

Tobias H. Tröger

Markus Behn

Rainer Haselmann

Vikrant Vig

Volker Wieland

Maik Wolters

Hermann Remsperger

Athanasios Orphanides

Michael Binder

Marcel Bluhm

Helmut Siekmann

Tilman Bletzinger

Volker Wieland

Tobias H. Tröger
A Theory of the Boundaries of Banks with Implications For Financial Integration and Regulation

The Political Economy of Bank Bailouts

Lending Standards, Credit Booms and Monetary Policy

Are Rules and Boundaries Sufficient to Limit Harmful Central Bank Discretion? Lessons from Europe

How Special Are They? - Targeting Systemic Risk by Regulating Shadow Banking

The Limits of Model-Based Regulation

Is there a threat of self-reinforcing deflation in the Euro area? A view through the lens of the Phillips curve

Der makroprudenzielle Komplex: der Prozess, das Schloss, das Urteil

What Happened in Cyprus? The Economic Consequences of the Last Communist Government in Europe

On the Conditional Effects of IMF Loan Program Participation on Output Growth

Zur Offenlegung der Bezüge von Sparkassenführungskräften im Internet

Financial Regulation and Supervision Across Business Lines in the United States - Financial Holding Companies post Gramm-Leach-Bliley Act Is Monetary Policy Overburdened?

Estimating the European Central Bank's "Extended Period of Time"

The Single Supervisory Mechanism Panacea or Quack Banking Regulation? 
72 / 2013

Matthias Burgert

Sebastian Schmidt

71 / $2013 \quad \begin{aligned} & \text { Helmut Siekmann } \\ & \text { Volker Wieland }\end{aligned}$

70 / $2013 \quad$ Elena Afanasyeva

69 / 2013 Tobias H. Tröger

68 / 2013 John F. Cogan

John B. Taylor

Volker Wieland

Maik Wolters

$67 / 2012 \quad$ Otmar Issing

Volker Wieland

66 / $2012 \quad$ John B. Taylor

Volker Wieland

$65 / 2012 \quad$ Helmut Siekmann

64 / 2012 Helmut Siekmann

$63 / 2012$

Guenter W. Beck

Kirstin Hubrich

Massimiliano Marcellino

62 / 2012

Volker Wieland

Maik H. Wolters

$61 / 2012$

John F. Cogan

John B. Taylor

Volker Wieland

Maik H. Wolters
Dealing with a Liquidity Trap when

Government Debt Matters: Optimal Time-

Consistent Monetary and Fiscal Policy

The European Central Bank's Outright Monetary Transactions and the Federal Constitutional Court of Germany (publ. partially as "The question before the court", in: Economist, June 18, 2013)

Atypical Behavior of Credit:

Evidence from a Monetary VAR

Konzernverantwortung in der aufsichtsunterworfenen Finanzbranche (publ. in: ZHR 2013, S. 475-517)

Fiscal Consolidation Strategy: An Update for the Budget Reform Proposal of March 2013

Monetary Theory and Monetary Policy: Reflections on the Development over the last 150 Years

Surprising Comparative Properties of Monetary Models: Results from a new Model Database

Missachtung rechtlicher Vorgaben des AEUV durch die Mitgliedstaaten und die EZB in der Schuldenkrise (publ. in: Thomas M.J. Möller und FranzChristoph Zeitler (ed.), Europa als Rechtsgemeinschaft - Währungsunion und Schuldenkrise, Tübingen 2013, pp.97-154)

Die Legende von der verfassungsrechtlichen Sonderstellung des „anonymen“ Kapitaleigentums (publ. in: Der grundrechtsgeprägte Verfassungsstaat, Festschrift für Klaus Stern zum 80. Geburtstag, herausgegeben von Michael Sachs und Helmut Siekmann, Berlin, 2012, pp. 1527-1541)

On the Importance of Sectoral and Regional Shocks for Price Setting

Forecasting and Policy Making

Fiscal Consolidation Strategy (publ. in: Journal of Economic Dynamics and Control, Vol. 37 Issue 2 (February), pp. 404-21) 